\title{
Management strategies for coral reefs and people under global environmental change: 25 years of scientific research
}

\author{
Comte Adrien ${ }^{1,{ }^{*}}$, Pendleton Linwood ${ }^{2}$
}

${ }^{1}$ Université de Brest, Ifremer, CNRS, UMR6308 AMURE, IUEM, Plouzané, France

${ }^{2}$ Duke University, Durham, NC, United States

* Corresponding author : Adrien Comte, email address : adrien.comte@univ-brest.fr

\begin{abstract}
:
Coral reef ecosystems and the people who depend on them are increasingly exposed to the adverse effects of global environmental change (GEC), including increases in sea-surface temperature and ocean acidification. Managers and decision-makers need a better understanding of the options available for action in the face of these changes. We refine a typology of actions developed by Gattuso et al. (2015) that could serve in prioritizing strategies to deal with the impacts of GEC on reefs and people. Using the typology we refined, we investigate the scientific effort devoted to four types of management strategies: mitigate, protect, repair, adapt that we tie to the components of the chain of impact they affect: ecological vulnerability or social vulnerability. A systematic literature review is used to investigate quantitatively how scientific effort over the past 25 years is responding to the challenge posed by GEC on coral reefs and to identify gaps in research. A growing literature has focused on these impacts and on management strategies to sustain coral reef social-ecological systems. We identify 767 peer reviewed articles published between 1990 and 2016 that address coral reef management in the context of GEC. The rate of publication of such studies has increased over the years, following the general trend in climate research. The literature focuses on protect strategies the most, followed by mitigate and adapt strategies, and finally repair strategies. Developed countries, particularly Australia and the United States, are over-represented as authors and locations of case studies across all types of management strategies. Authors affiliated in developed countries play a major role in investigating case studies across the globe. The majority of articles focus on only one of the four categories of actions. A gap analysis reveals three directions for future research: (1) more research is needed in South-East Asia and other developing countries where the impacts of GEC on coral reefs will be the greatest, (2) more scholarly effort should be devoted to understanding how adapt and repair strategies can deal with the impacts of GEC, and (3) the simultaneous assessment of multiple strategies is needed to understand trade-offs and synergies between actions.
\end{abstract}




\section{Highlights}

- We develop a typology of management strategies for coral reefs and people under GEC. Using this typology we review research efforts on management strategies over 25 years. Half of all case studies focus on corals reefs in Australia and the United States. Most research focuses on marine protection; repair \& adapt strategies need attention. Developing countries in the Indo-Pacific and the Caribbean are poorly studied.

Keywords : Coral reefs, Climate change, Ocean acidification, Management, Adaptation 


\section{Introduction}

Ocean acidification (OA) and climate change, including rising sea surface temperatures (SST), change in cyclone patterns, sea-level rise, and de-oxygenation, will adversely affect coral reef ecosystems in the coming decades (Cinner et al., 2016; Hoegh-Guldberg et al., 2014; Pendleton et al., 2016b). These global environmental changes (GEC) and their interactions will impact the goods and services provided by coral reefs upon which human populations depend (Brander et al., 2012; Pendleton et al., 2016a). Coral reefs support local and national economies (Burke et al., 2011), for instance by providing habitats for many species of fish on which local fishers depend (Teh et al., 2013), but also providing revenues from tourism and coastal protection. People, communities, and nations are vulnerable to the effects of GEC on coral reefs (Hughes et al., 2012).

Identifying ecosystems and human populations that are vulnerable to environmental change does not shed much light on appropriate response strategies (Hinkel, 2011). Vulnerability or impact assessments do not systematically identify which actions could reduce vulnerability (Tulloch et al., 2015). A necessary approach to reduce impacts and vulnerability is to identify the range and mix of possible actions (Ranger and Garbett-Shiels, 2012; Wilby and Dessai, 2010). Several scientific papers have attempted to help decision-makers and managers deal with the adverse effects of GEC on coral reefs by identifying management options (e.g. Mcleod et al., (2013); Rau et al., (2012)). However, they often focus on a narrow set of actions that can be taken within a specific management approach such as Marine Protected Areas (e.g. Green et al., 2014; Keller et al., 2009), a specific threat (e.g. ocean acidification) or a specific ecological process such as coral adaptation to warming (van Oppen et al., 2015). Of course, not all strategies are available or recommended in every situation, but a focus on too few strategies can be misleading (e.g. protective measures (Hilborn, 2016)). Evaluating a broader range of available strategies, and indeed combinations of actions, helps managers to estimate the trade-offs of different management approaches (Bozec et al., 2016). Multiple strategies may be needed to deal with different parts of the problem.

A new science of solutions is emerging to help guide the choice of action, especially regarding climate change adaptation (Hinkel and Bisaro, 2015; IPCC, 2014). A synthesis of management strategies, based on an understandable conceptual framework can help managers and decision makers consider different policy actions within the complexity of coral reefs social-ecological systems (SES). Such a typology of management strategies has the advantage of making sense of a large number of actions while enabling conditions to evaluate and articulate their advantages and barriers (Biagini et al., 2014). It is therefore important to evaluate the broad range of possible management strategies available in a typology, in order to implement the most appropriate strategies and to avoid maladaptation (Magnan et al., 2016).

One common way of dividing solutions to climate change, used by the Intergovernmental Panel on Climate Change (IPCC), is between mitigation and adaptation (IPCC, 2014). Mitigation involves reducing the amount of greenhouse gases (GHG) while adaptation involves solutions to cope and to adapt to the adverse effects of climate change. This dichotomy reflects societal decisions but does not fully reflect the complexities of social-ecological systems. A number of management strategies, notably on coral reefs 
SES, show that mitigation and adaptation actions are not exclusive. The concept of adaptation to climate change usually only includes human adaptation, therefore fails to reflect the ecological components of coral SES. A typology that encapsulates the societal as well as the ecological components of the system is therefore needed.

Gattuso et al. (2015) proposed a typology to deal broadly with the impacts of carbon dioxide $\left(\mathrm{CO}_{2}\right)$ on the marine environment. Four major categories of actions are described in this typology to reduce the risk posed by $\mathrm{CO}_{2}$ on ocean ecosystems and ecosystem services: mitigate, protect, repair, adapt. We do not know of literature reviews that attempt to use this typology for coral reefs SES and therefore we build on this typology and refine it specifically for coral reefs SES.

In addition to constructing a typology, a systematic literature review is important to investigate how science is currently addressing solutions to respond to the challenge posed by GEC on coral reefs. First, science has a critical role to play in shaping adaptation policy and reducing vulnerability of the marine environment (Ekstrom et al., 2015), and in guiding the allocation of resources (Di Marco et al., 2017). An understanding of the global scientific endeavor can help guide future research and better integrate science in policy-making. Second, we do not know of any evaluation that attempts to link the current scientific effort devoted to managing GEC and coral reefs and that evaluates the degree to which this scientific effort covers places that contain high biodiversity, provides ecosystem services, and will be the most affected by GEC. The spatial distribution of exposure and of dependence on ecosystem services is not homogeneous (Pendleton et al., 2016a). Because of this uneven spatial distribution, it is important to evaluate whether the scientific literature sheds light on the places that will be the most impacted.

The first goal of this paper is to review the scientific literature to structure, using a typology, the suite of management actions that could be available to deal holistically with the entire chain of GEC impacts from climate change and OA on coral reefs, their resilience, and the services they provide to people. This typology organizes information to enable managers and decision-makers to assess the effectiveness of actions in their local settings. The second goal of this paper is to understand how the scientific effort targeted at coral reefs, GEC, and management is distributed through space, time, and categories of action. Through this systematic literature review, we hope to identify gaps in the global coverage of research and also gaps in our understanding of the range of strategies to deal with the impacts of GEC.

\section{A revised typology of management strategies}

\subsection{Constructing a typology for management strategies of coral reefs and people under GEC}

The typology presented in Gattuso et al. (2015) classifies management strategies into four major categories: mitigate, protect, repair, and adapt. This typology was designed to broadly identify actions to 
tackle climate change and ocean acidification for ocean ecosystems and the services they provide. To apply this typology to tackle the impacts of GEC on coral reefs ecosystems and ecosystem services, we created sub-categories to take into account specific aspects of coral reef management (Figure 1). When refining Gattuso et al.'s typology to deal with coral reefs ecosystems, the same four categories of management strategies can be used: reduction of local and global threats (mitigate), repairing and restoring damaged reefs and associated ecosystems (repair), protecting existing healthy ecosystems to improve resilience and maintain ecosystem functions (protect), and adapting human societies to the reduction of ecosystem services when damage from environmental change is not avoidable (adapt) (Burke et al., 2011; Gattuso et al., 2015; Mumby and Anthony, 2015).

Coral reef management focus on different aspects of the chain of impacts. Some are dedicated to conservation, while others target socio-economic vulnerability. We focus on public policy actions to tackle the threat that high $\mathrm{CO}_{2}$ poses on coral reefs and human populations who depend on them. Private responses to these threats have been analyzed in Evans et al. (2016). We compile actions that can be implemented by local, national or international managers and decision-makers from the literature. We use the analytical framework developed by (Gattuso et al., 2015) as the basis to categorize possible options. Taken together, they give a broad picture of actions across all components of coral reefs SES. We provide a brief overview of the Gattuso et al. typology and an explanation of our modifications. Differences between the two typologies are presented in SM2. For a more exhaustive list and discussion of available actions, see SM3. 


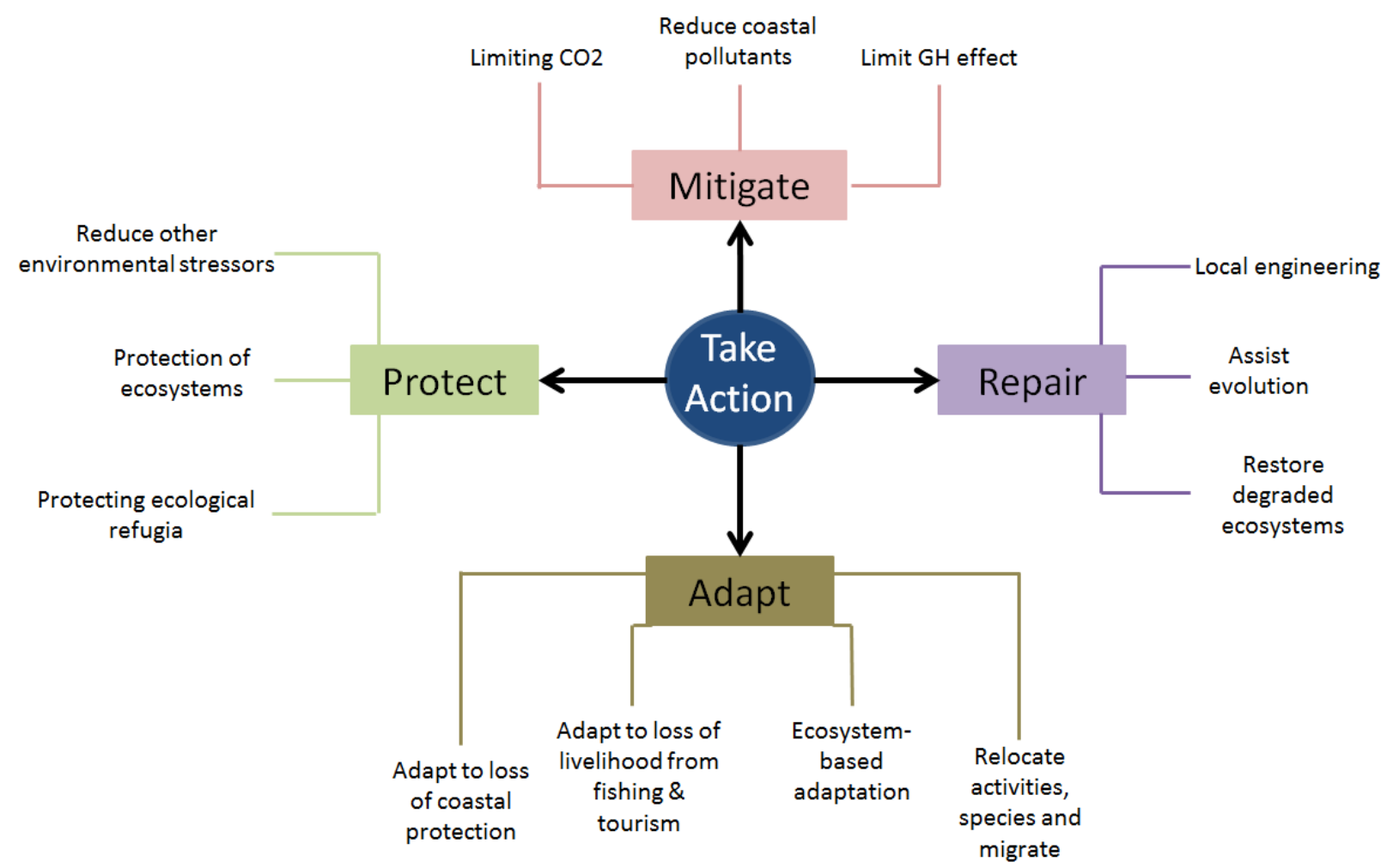

Figure 1: Typology of management strategies to deal with GEC on coral reefs and people who depend on them; modified from Gattuso et al. (2015)

The main strategy to deal with climate change and ocean acidification is the reduction of greenhouse gases and coastal pollution. These "Mitigate" strategies can be broken down into three major subcategories, limiting $\mathrm{CO}_{2}$ emissions, reducing the greenhouse effect, and reducing coastal pollution. In agreement with Gattuso et al. (2015), we include coastal pollutants in the mitigate category, since these actions directly interact with ocean acidification and sometimes temperature (with turbidity). Measures to improve water quality can mitigate the effects of ocean acidification locally (Kelly et al., 2011). Reducing pollution, nutrient loading and sediments runoff also affects the state and resilience of coral reefs. Other environmental factors influence the resilience of ecosystems, and are addressed in the category "Protect".

Another set of actions builds on the notion of protection of coral reefs from local anthropogenic activities to improve the resilience of coral reefs to global environmental changes, broadly interpreted to include Marine Protected Areas (MPAs), marine spatial planning, and fisheries closure areas. Following the original framework, "Protect" strategies can be broken down into three major sub-categories, reducing local stressors to improve resilience, protection of ecosystems and associated ecosystems in MPAs, and protection of ecological refugia. We distinguish between fully protected MPAs or no-take marine reserves (Roberts et al., 2017) and other area-based management approaches placing the 
former in the "protection of ecosystems" sub-category and the latter in the "reduce other environmental stressors" sub-category.

Once coral reefs and associated ecosystems are degraded due to human impacts or natural phenomena (e.g. diseases and cyclones) and after they experience the effects of GEC, it could be possible to implement actions to restore biodiversity and lost ecosystem functions. These "Repair" strategies can be broken down into three major sub-categories, restoring lost ecosystems, assisting evolution, and using local engineering to buffer against global environmental change. It could be possible to restore unharmful environmental conditions for coral reefs at a very localized scale. These actions are categorized under the "local engineering" sub-category and include a more diverse set of actions than those enumerated in the Gattuso et al. (2015) typology that only considered adding alkaline material. Various other techniques are being developed to locally buffer against the unavoidable changes in ocean temperature and $\mathrm{pH}$ such as artificial shading to cool local areas (Rau et al., 2012). These methods are different from mitigate measures because they repair harm after it is done, while mitigation is here to prevent environmental changes.

Finally, "Adapt" strategies are those that assume future impacts of GEC will occur and help people cope with this new reality. The three types of strategies described above focus mainly on the ecological health and resilience of coral reefs, but not on the human activities and livelihoods that depend on coral reefs. Actions that address human adaptation to the loss of ecosystem services provided by coral reefs needs to be understood since climate change will and is already damaging coral reefs worldwide. While the typology developed by Gattuso et al. (2015) broadly addressed the adaptation of human activities and communities, we tailor these management strategies to the ecosystem services associated with coral reefs, the main ones being coastal protection, fisheries, and tourism. In addition, humans can harness nature to help societies adapt to the adverse effects that climate change will have on human systems, an approach that has been described by several authors as ecosystem-based adaptation (Jones et al., 2012). Adaptation strategies can be broken down into three major sub-categories: adapting to the loss of ecosystem services, using ecosystem-based adaptation, and relocation or migration of activities and populations.

In addition to these four types of strategies, there also are indirect strategies that focus on improving the underlying social, governance, and economic conditions necessary for the other four types of strategies to be effective. They can be divided in two categories: research and monitoring, and building capacity and are also detailed in SM3.

\subsection{Linking Management strategies to the impacts of GEC on coral reefs SES}

The chain of impacts that link global environmental change to coral reefs and societies who depend on them is complex (Figure 2). Local and global threats already have adverse impacts coral reefs. Local threats include coastal and marine pollution, overfishing, invasive species, crown-of thorn starfish, and 
physical damages. Global threats include sea temperature change, OA, and cyclones. For example, ocean acidification will impact calcification, but also other processes important for coral reefs development including reproduction, growth, and metabolism (Pendleton et al., 2016b). These changes may also produce opportunities for coral reefs and people, cyclones reduce sea surface temperature locally for instance. In turn, the degradation of reefs will affect ecological functions and species diversity that support the provision of services to human populations, including coastal protection, fisheries, and tourism. The purpose of management strategies is to reduce ecological exposure or sensitivity (Figure 2) (Engle, 2011). Ecological exposure refers to the hazards (global and local environmental changes) as well as the health of coral reefs. Social vulnerability refers to the dependence of people on healthy coral reefs and their capacity to adapt.

All mitigate strategies target the reduction of ecological exposure, through the reduction of global and local environmental changes. Repair strategies also target ecological exposure, since they aim to improve coral reefs health under climate change. However, it is possible that restoration of degraded ecosystems could increase ecological exposure if it is done in regions where hazards will be more severe in the future (Fadli et al., 2012). In addition, the impacts of repair strategies on social vulnerability are not clear. Repair strategies could improve ecosystem services in the future by increasing coral reef cover and functions, but the distribution of these potential benefits across space and time has not been addressed in the literature. Protect strategies also target ecological exposure since their main purpose is to reduce and prevent anthropogenic pressures. The effect of protect management strategies on social vulnerability is unclear since these strategies, particularly no-take marine reserves, may have beneficial effects (e.g. through spillover of fish or by protecting reef structure important for shoreline protection), but could exclude some or all human activities and populations including those who depend on reefs for nutrition (Hilborn, 2016). Of course, even in the absence of protection, unsustainable levels of exploitation may also imperil the future of coral reefs. Adapt strategies are the only strategies explicitly targeted at reducing social vulnerability and the dependence of populations on coral reefs ecosystem services. Adaptation policies on land may threaten coral reefs socio-ecological systems (Evans et al., 2016). The use of ecosystem-based adaptation has the co-benefit of protecting ecosystems and restoring ecosystems, but these may not be viable solutions if climate change affects the capacity of these systems to provide ecosystem services (Pendleton et al., 2016a). 


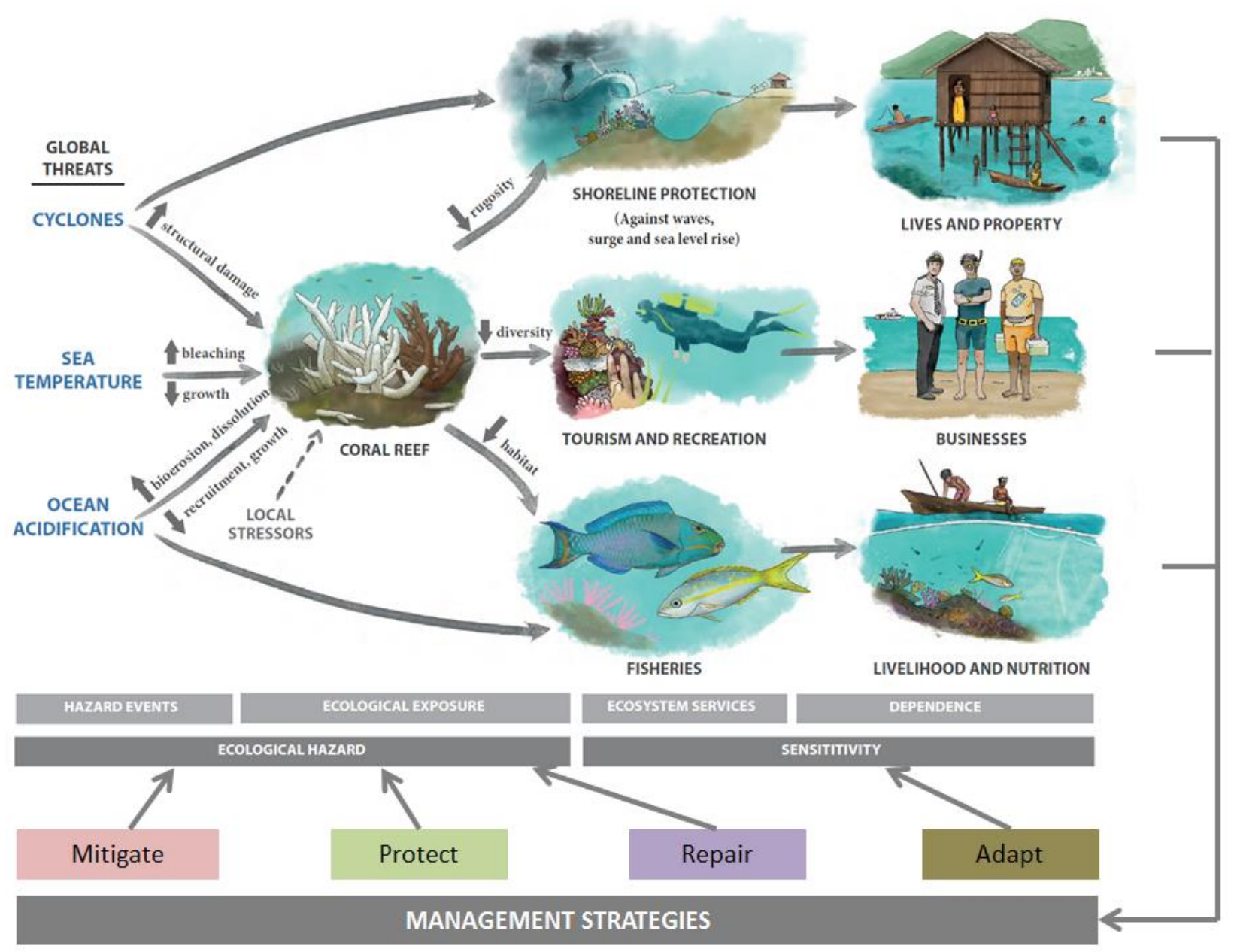

Figure 2: Influence of the four categories of management strategies on the chain of impacts of climate change and ocean acidification on coral reefs and people dependent on the services provided by coral reefs; modified from Pendleton et al., (2016a).

\subsection{Conceptual ramifications of constructing a typology of management strategies for coral reefs SES}

The typologies used in the literature are not always consistent. In several research articles, especially focusing on vulnerability (Cinner et al., 2013; MacNeil et al., 2010), "adaptation" is used to refer to strategies that increase the ecological resilience of the biological system while others use climate adaptation to refer to actions that enhance ecosystem services provisions under climate change (Arkema et al., 2013). Since this definition of adaptation refers to the reduction of vulnerability to the impacts of climate change, such measures may fall in three of our categories: protect, repair, and adapt depending on the definition of the systems under study. For example, mangrove restoration contributes to carbon sequestration (mitigate), resilience of coral reefs ecosystems (protect), and coastal population adaptation (adapt) (Duarte et al., 2013). Gattuso et al. (2015) use the term "adapt" to refer to adaptation 
of the society to the loss of ecosystems and ecosystem services, thus distinguishing between actions focusing on the ecology and actions focusing on human populations. Measures to improve the resilience of the ecosystem, as opposed to the resilience of the human society, are presented in the protect section. However, there are measures that use ecosystems to help human societies adapt to the adverse effects of climate change (i.e. ecosystem-based adaptation), and these are presented as adaptation strategies but rely on other strategies such as restoration.

Management actions tend to reflect approaches that differ along two important dimensions: 1) maintain/change - where actions fall along a gradient from those that seek to maintain the ecological and environmental status quo (or some previous state) to those that deal with future change, and 2) nature/society - where some actions attempt to directly influence natural conditions and others focus on influencing human aspects (Figure 3). These two dimensions are important to understand which disciplines focus on which approaches. They may also reflect the preferences of managers and institutions that promote climate action and management. The protect and mitigate management strategies can be thought as conventional strategies since they involve a reduction in human activities (e.g. pollution, emission of $\mathrm{CO}_{2}$, fishing) that has been promoted for many decades. Repair and adapt management strategies are the focus of recent innovation since they often require the change or the initiation of new activities (e.g. restoring coral reefs, changing economic activities) that has emerged more recently in the literature (Füssel and Klein, 2006). The mitigate and adapt categories of management strategies parallel the ones developed by the IPCC and used in the United Nations Framework Convention on Climate Change (UNFCCC) and apply mostly to societal responses and actions (Schipper, 2006). The protect and repair categories of management strategies mostly apply to natural systems. Together, these two dimensions serve to ground management strategies in a socio-ecological system framework. 


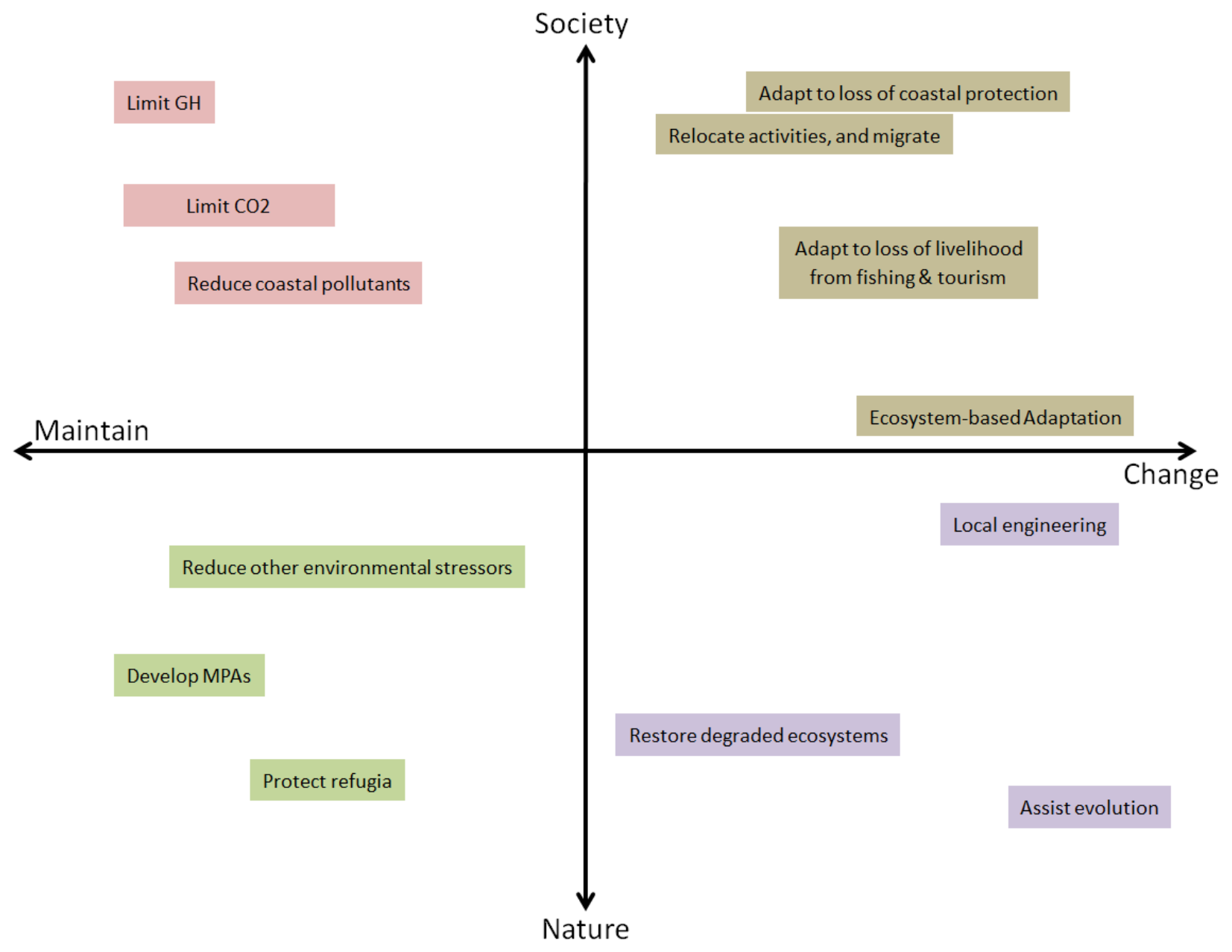

Figure 3: The sub-categories belonging to the four categories of management strategies (mitigate in red, protect in green, repair in purple, and adapt in brown) fall along two axes: maintain/change and nature/society

\section{Material and Methods}

We systematically searched the Web of Science and Scopus databases for articles, published from 1990 to 2016, that addressed coral reefs, climate change or ocean acidification, and that were action-oriented (see SM1 for equations to retrieve these articles). After deleting duplicates, 1177 references were found. A first screening on title of publication, title of journal, abstract, and key words removed articles that did not apply to coral reefs and associated ecosystems (e.g. general papers on $\mathrm{CO}_{2}$, on cold water corals). Only peer reviewed articles were selected, acknowledging that important contributions may come from books, book chapters and the grey literature. 885 papers remained. After selecting for remaining 
references that had a component relevant for management or explicitly stated management implications based on title of publication and abstract, 767 publications remained.

Key words were used to assign categories of management strategies (mitigate, protect, repair, adapt, indirect) to the research articles. The Intellixir@ software used for the treatment of the literature produced its own list of around 20,000 candidate concepts. A list of action-oriented concepts for each category was created based on this list. Several candidate concepts that describe actions were not explicit enough to fit a category of the typology (e.g. "Facilitate coral persistence") and were discarded. Strategies are not always single-objective and could apply to more than one category in the typology. For example, "ecosystem management" or "ecosystem recovery" are terms that include a very broad category of actions. Other concepts indicating properties of a system such as "adaptation" and "resilience" could be applied to different parts of the systems, therefore limiting our ability to categorize research articles.

The final list of action-oriented concepts contains 228 concepts for the mitigate category, 138 for the repair category, 210 for adapt, 414 for protect, and 267 for the indirect category. These concepts were applied to the title, abstract, and key words of articles to categorize them. It was possible to assign one or more categories of management strategies to 690 out of 767 papers, or $90 \%$ of them. The remaining research articles either were too vague, broadly mentioned having implications for management without detailing how in their abstract, or in a few cases abstract was not accessible.

All contributing authors to the articles reviewed here were assigned to a country based on their affiliations. One caveat is that countries with overseas territories (France, UK, USA, and the Netherlands) sometimes have affiliations in both overseas territories and the mainland (note that these countries already produce the largest number of articles). Titles and abstracts of the 767 articles were screened to determine if they referred to case studies and the country or countries where these case studies were located. To understand whether social, demographic, economic, or ecological characteristics played a

role in the location of studies, we collected data on attributes of countries including Gross Domestic Product (GDP) per capita (average between 2006 and 2013 in current US\$, source: The World Bank, 2017), coral extent (source: UNEP-WCMC, WorldFish Centre, WRI, 2010), and ecosystem services (source: Pendleton et al., 2016a). A Principal Component Analysis (PCA) with hierarchical classification was conducted using the software " $R$ " (with the packages Rcmdr and FactoMineR) to determine how the variability of countries was distributed across these variables and to understand how countries clustered around these variables.

\section{Results}

\subsection{Distribution of the scientific efforts}


There are 767 peer reviewed research articles included in this analysis. Seventy-seven research articles contain no explicit management action in their title, key words or abstract but state that their work is relevant for management. Actions that can be associated with at least one of the four management categories (mitigate, protect, repair, and adapt) are found in 599 research articles. Indirect actions are found in 362 research articles. For the articles that identify action in the four categories of direct management strategies, $61 \%$ discuss only a single category, while $39 \%$ discuss actions in two, three, or the four categories of management strategies (31\%, $7 \%$, and $1 \%$ respectively; Figure 4$)$. This suggests that a majority of research articles target a specific management strategy or a specific part in the chain of impacts, and therefore very few have a holistic scope. Nonetheless, this also shows that there are interactions between categories of management strategies that could be of two kinds: (i) actions that address two types of categories or (ii) research discussing a range of different solutions.

Several actions could be assigned to more than one category depending on their objectives. Typically, restoration of degraded ecosystems linked to coral reefs, including mangroves, wetlands, and seagrass, could fall in the repair, protect, or adapt category depending on their purpose and timing. Some of these measures actually serve more than one purpose. Mangrove restoration is beneficial in terms of carbon sequestration and therefore mitigates $\mathrm{CO}_{2}$ emissions, at the same time it improves the resilience of coral reefs as an important habitat for young reef fish and through buffering $\mathrm{pH}$ locally, and serves as a natural substitute for lost coral ecosystems services (including as a cite for fisheries and a natural barrier for coastal protection of human population). Similarly, fisheries management can improve reef resilience and provide food security to people. MPAs could implement fisheries management, disease control, and marine and coastal pollution management (Keller et al., 2009), thus fitting in the protect and the mitigate categories.

Mitigate strategies are identified in 180 articles, protect in 411 articles, repair in 110 articles, and adapt in 181 articles (Figure 4). The protect category, and especially MPAs is the most cited strategy in the research articles reviewed here. Many articles exclusively discuss this strategy with respect to climate change, particularly the design of MPAs, their effectiveness, or their implementation. This is coherent with the historic way of thinking and tools used for biodiversity conservation (Lubchenco et al., 2003; Roberts et al., 2002). 

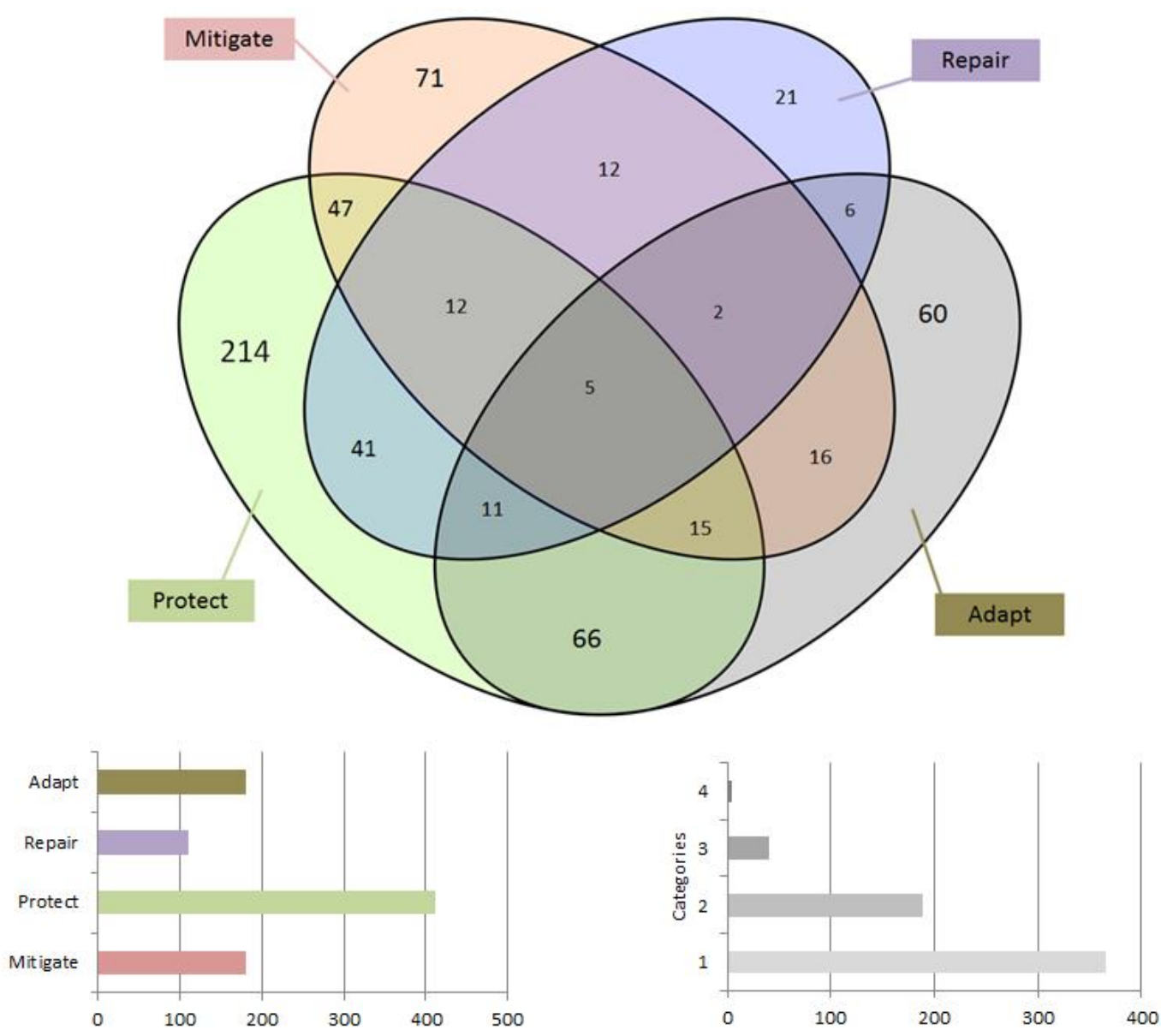

Figure 4: Euler diagram of the number of actions identified in each category of management strategies, and the ones that overlap one or more categories. The same information is then broken up by category of management strategy and by number of categories address in research articles

\subsection{Changing scientific effort over time}

There is a growing literature on the management of coral reefs and human populations to combat GEC (Figure 5A). The engagement of the scientific community with this topic started later for coral reefs than for climate change in general, after the first global bleaching event of 1998. The number of peerreviewed articles on the subject has steadily increased over the years especially after the second global bleaching event that occurred in 2005. The acceleration in publication rate started ten years ago and the number of articles tripled between 2009 and 2016, from 45 in 2009 to 156 articles in 2016. This rapid increase in publications over the years directly parallels the increase in scientific production in peer reviewed journals for the whole field of climate change (Figure 5B). The increasing number of publications can be explained by the same factors that influence climate change and ocean acidification research in general, including global recognition of this topic, international collaborations (Riebesell and 
Gattuso, 2015) and the global review of ecosystems and ecosystem services (Millenium Ecosystem Assessment, 2005). Indeed, the focus on management of coral reefs under threat started with the creation of the International Coral Reef Initiative (ICRI) and the Global Coral Reef Monitoring Network (GCRMN) in 1994.
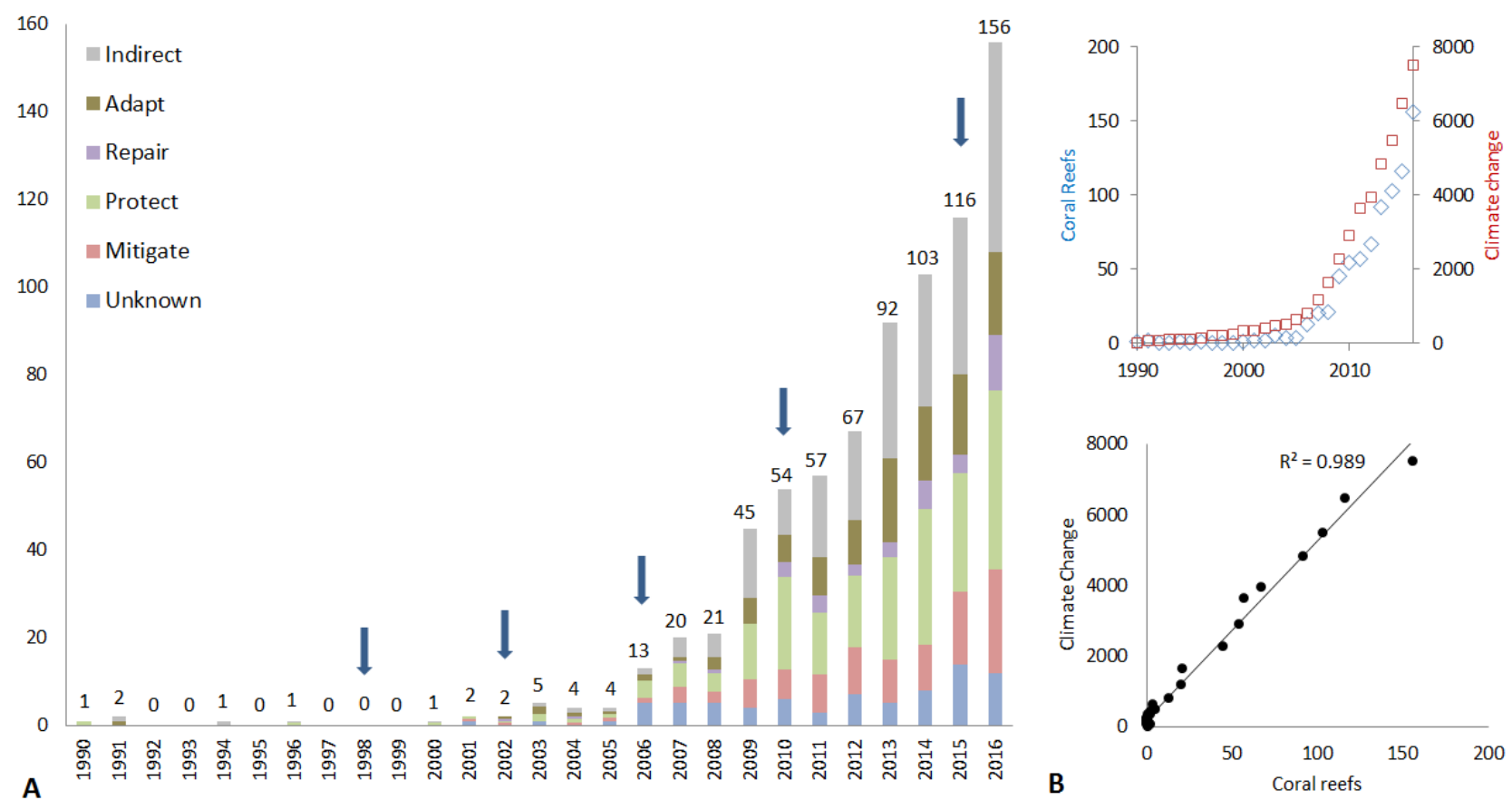

Figure 5: Temporal analysis of action-oriented scientific effort on coral reefs and GEC, compared with climate change as a whole. (A) Number of research articles found per year, from 1990 to 2016, broken down by categories. Arrows represent global bleaching events in 1998, 2010, and 2015-16. Large scale bleaching also happened in Australia in 2002 and 2006, and in the Caribbean in 2006; (B) Comparison of coral reefs publications over the years with publications for the whole field of climate change research

(see SM1 for methodology).

Over the past ten years, the relative effort on the four direct action categories has remained fairly constant in the literature (Figure $6 \mathrm{~A}$ ). About $20 \%$ of the actions identified are mitigate actions, about $50 \%$ are protect actions, about $10 \%$ are repair actions and $20 \%$ are adapt actions. The relative proportion of the repair category has increased just recently. The rates of change in publications over time, however, are different across the four categories of management strategies (Figure 6B). Protect has the highest rate of increase in publications over the years, followed by mitigate, adapt, and repair. The relative stability of these proportions over time could reflect a dominant thinking in the research community towards the use of protect measures, with a minority of researchers considering solutions for social and economic consequences of a loss of coral reefs (and therefore human populations and ecosystem services). 


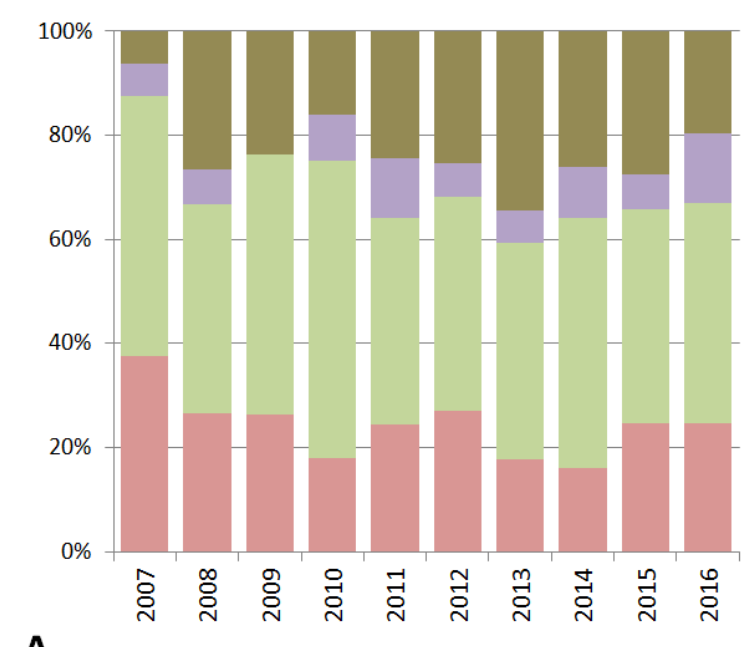

A

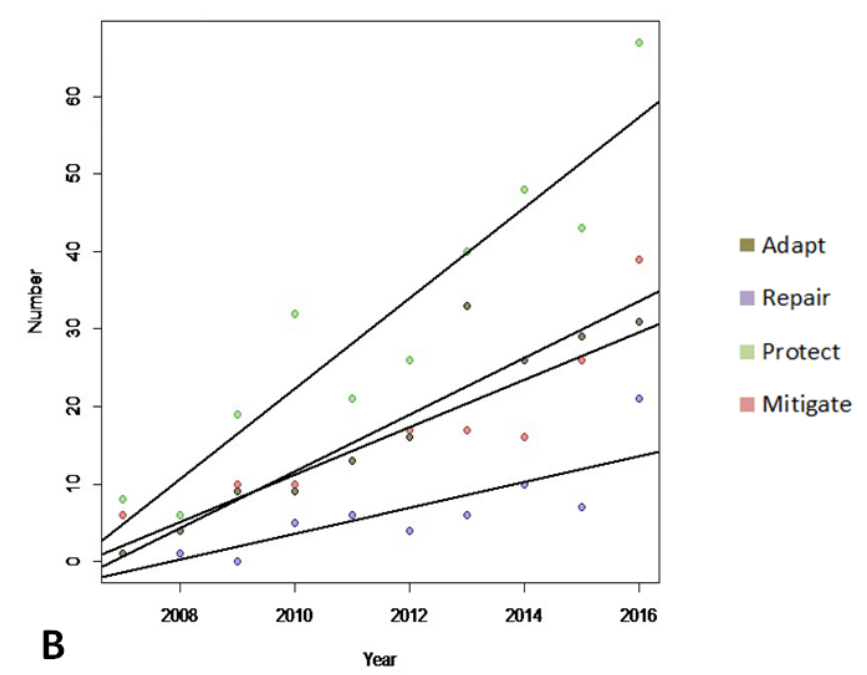

Figure 6: Temporal evolution of the four management strategies over the last decade (2007-2016), (A) in proportional terms and $(B)$ in absolute terms (with ANCOVA, $r^{2}=0.8849$ )

\subsection{Scientific effort varies around the world}

The scientific literature is authored by researchers from 89 countries or territories. The vast majority of scientific articles reviewed here are co-authored by researchers who are affiliated with institutions in Australia (388) and/or in the United States (335). Authors' affiliated with institutions in other developed countries, including Canada and European countries also represent a large share of the publications. This pattern holds on aggregate and for all four types of management strategies (Figure S1), suggesting that the origin of authors does not influence the type of management strategy studied. Forty-four countries or territories containing coral reefs do not have any authors publishing management-focused studies on coral reefs and GEC, including in the Caribbean and the Indo-Pacific region.

Half of the studies (50.5\% or 387 out of 767 ) include case studies, which are located in 84 countries or territories. In addition to these 387 case studies that range from focusing on a single reef to a handful of countries like the Coral Triangle, 19 research articles focus on regional scale management (10 in the Caribbean, others in the Indo-Pacific or Pacific Islands) and are not counted as case studies. The highest number of case studies are located in Australia (132 case studies) and particularly in the Great Barrier Reef (Figure S2). Other case studies are mainly located in the United States, the Coral Triangle, the Caribbean, and the Western Indian Ocean. The case studies examined focus primarily on protect strategies, and focus the least on repair strategies (the highest number of case studies focusing on repair strategies in a single country is 14 in the United States). This proportional distribution of case studies focusing on the four categories of management strategies is the same for each region of the world. The same pattern holds looking at affiliations or case studies (Figures S1, S2). 
Three main factors could explain the spatial distribution of authors and case studies across the globe: the locations of corals, the wealth of countries that are able to sustain research institutions and the services that reefs critically provide to populations. Authors tend to be located in institutions in high income countries and not necessarily in the countries with the highest coral extent. Developed countries play a major role in conducting research on coral reef management in developing countries in which the resources to conduct research are limited. Indeed, $42 \%$ of case studies are authored by researchers affiliated in a different country or territory than where the study is located. Twenty-nine percent of case studies are authored exclusively by researchers in the country where it is located, $27 \%$ include both authors affiliated in the country of the case study and foreigners, and $2 \%$ of the studies were conducted in overseas territories by authors affiliated in the mainland. For instance, $80 \%$ of the case studies coauthored by researchers affiliated in the United States are located outside of the United States. This pattern is influenced by at least two factors: (1) coral reefs are located in the tropics, where most developing countries are also located, and (2) several developed countries, including the United States, the United Kingdom, and France possess overseas territories where coral reefs are located.

To gain a deeper insight into the factors influencing why and where case studies are conducted, a PCA was applied to the same factors that could influence their locations. Two outliers, Australia and the United States, both outliers characterized by very high amounts of case studies, were excluded from this analysis. Two dimensions of the PCA account for $74.45 \%$ of the variability in the data (Figure 7). The variables factor map (Figure 7A) shows that coral extent is a primary explainer of where case studies are located. The value of ecosystem services co-varies with coral extent and case studies but does not seem to be a primary determinant of where coral reef management studies are conducted. GDP per capita is orthogonal to these two variables, suggesting that all things being equal, GDP per capita does not play a role determining where case studies are located. The choice of case studies is therefore primarily driven by where vast areas of corals are found.

A hierarchical clustering shows that countries fall into four distinct groups of countries when trying to understand the role of GDP, coral cover, and case studies (Figure 7B). The first cluster represents countries with very high GDP per capita like the Gulf countries, Bermuda, or Singapore. These countries could have the means to study coral reefs extensively but do not do so. The extent of coral reefs and ecosystem services is low in these countries. However, these countries may find it beneficial to invest in research on coral reef management since these are places that may be home to corals that are acclimated to future conditions (Fine et al., 2013). The second cluster contains small developing countries and island states such as Nauru, Aruba, Brunei Darussalam that are characterized by small coral extent, few case studies, and low GDP per capita. This cluster also includes middle-sized developing countries that have little or no case studies such as Cuba, Vietnam, or Panama. While these countries have less coral extent than other countries, local communities are likely to be highly dependent upon coral resources. As a result, investment in more research on coral reef management may have significant returns on investment. Lower middle income countries (as defined by the World Bank) found in this group are under-studied compared to their relative importance in terms of coral extent. The third cluster contains large countries such as Brazil, China and India, and countries with high coral extent with high levels of ecosystem services including Thailand and French Polynesia for example that contain more than 
average case studies. Finally, the fourth cluster regroups the Philippines and Indonesia that contain vast areas of coral reefs and high levels of ecosystem services, combined with numerous case studies. The number of case studies in these countries shows that regional and international research programs in the Coral Triangle should be encouraged. Twenty-six countries or territories containing coral reefs do not have case studies located in them. This is a serious gap, especially for Cuba and Eritrea which both contain large areas of coral reefs.

A

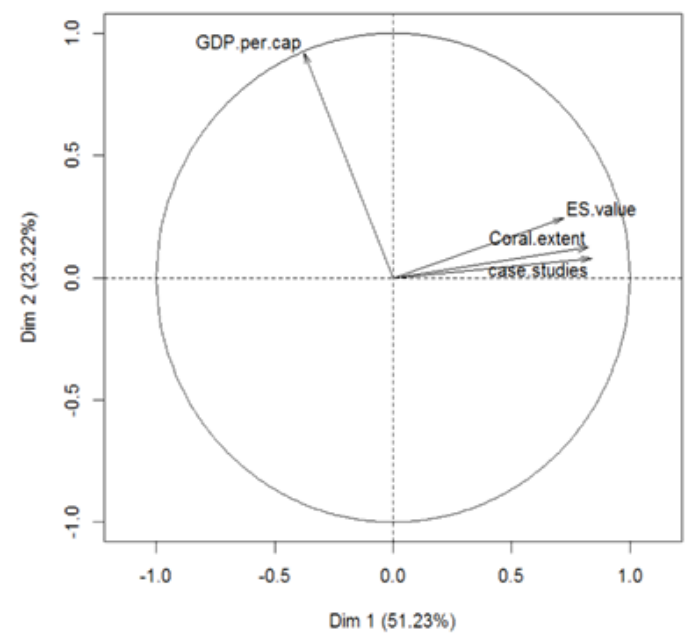

Variables factor map (PCA)

A

$\operatorname{Dim} 1(51.23 \%)$

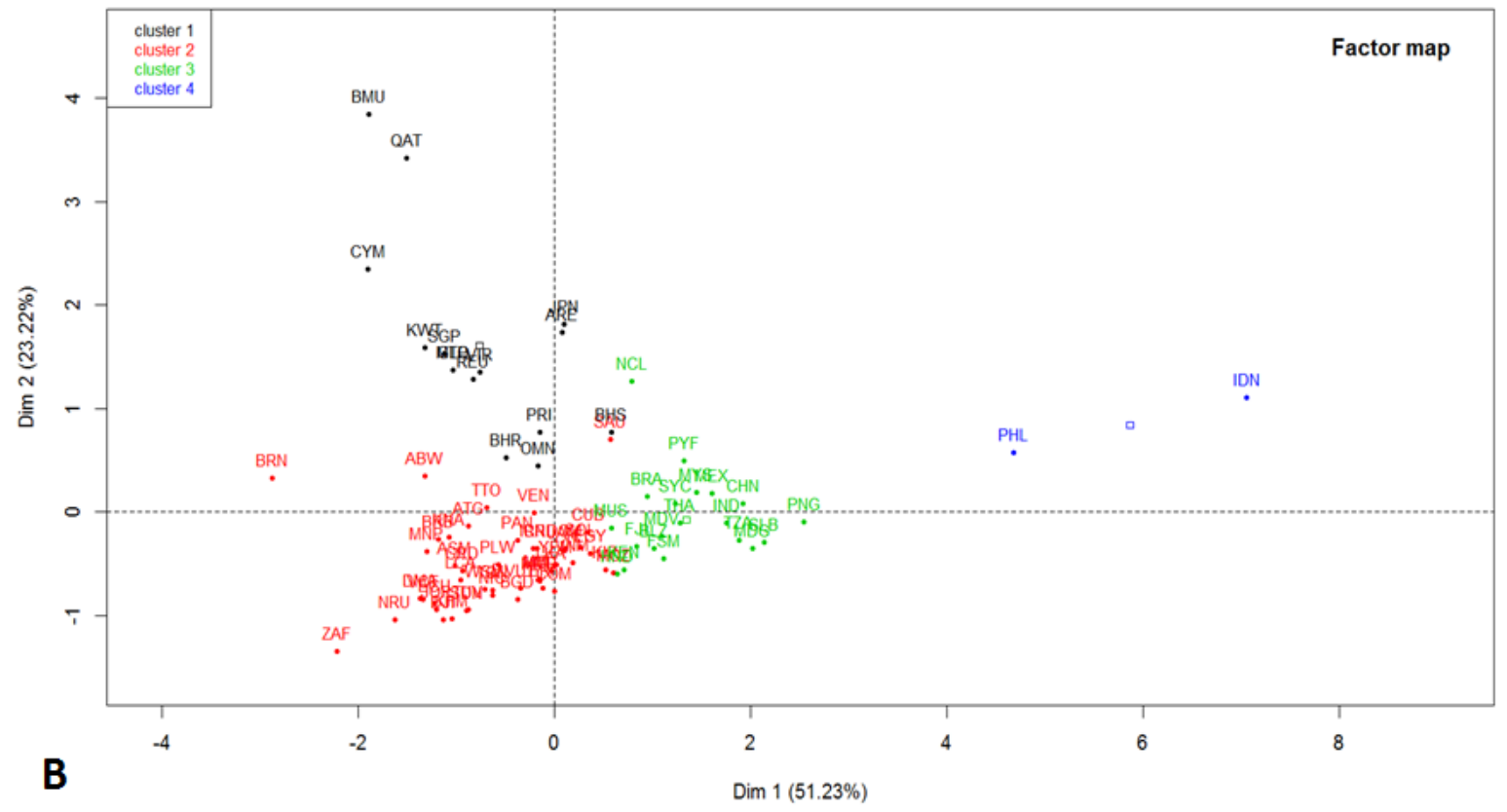

Figure 7: PCA analysis with hierarchical clustering on countries containing case studies, excluding Australia and the United States. (A) Variable factor map with GDP per capita, ES values, coral extent, and number of case studies and (B) factor map along the two first dimensions 
The distribution of future global environmental change is not homogeneous and science needs to study the effectiveness of management actions in those places where coral reefs and people may be most at risk from GEC. Current modelling suggests that SST warming will impact the Pacific and South-East Asia first, whereas OA will be more important towards the pole (Pendleton et al., 2016a). In addition, the distribution of the demand for ecosystem services is also heterogeneous, and South-East Asia is the most dependent on reefs for ecosystem services, followed by the Middle East, the Caribbean and the Indian Ocean (Figure 8). Comparing the average proportions of ecosystem services across ocean provinces with the proportion of case studies, there is a deficit of case studies in the Middle East, the South-East Asia, and the Brazilian ocean provinces.

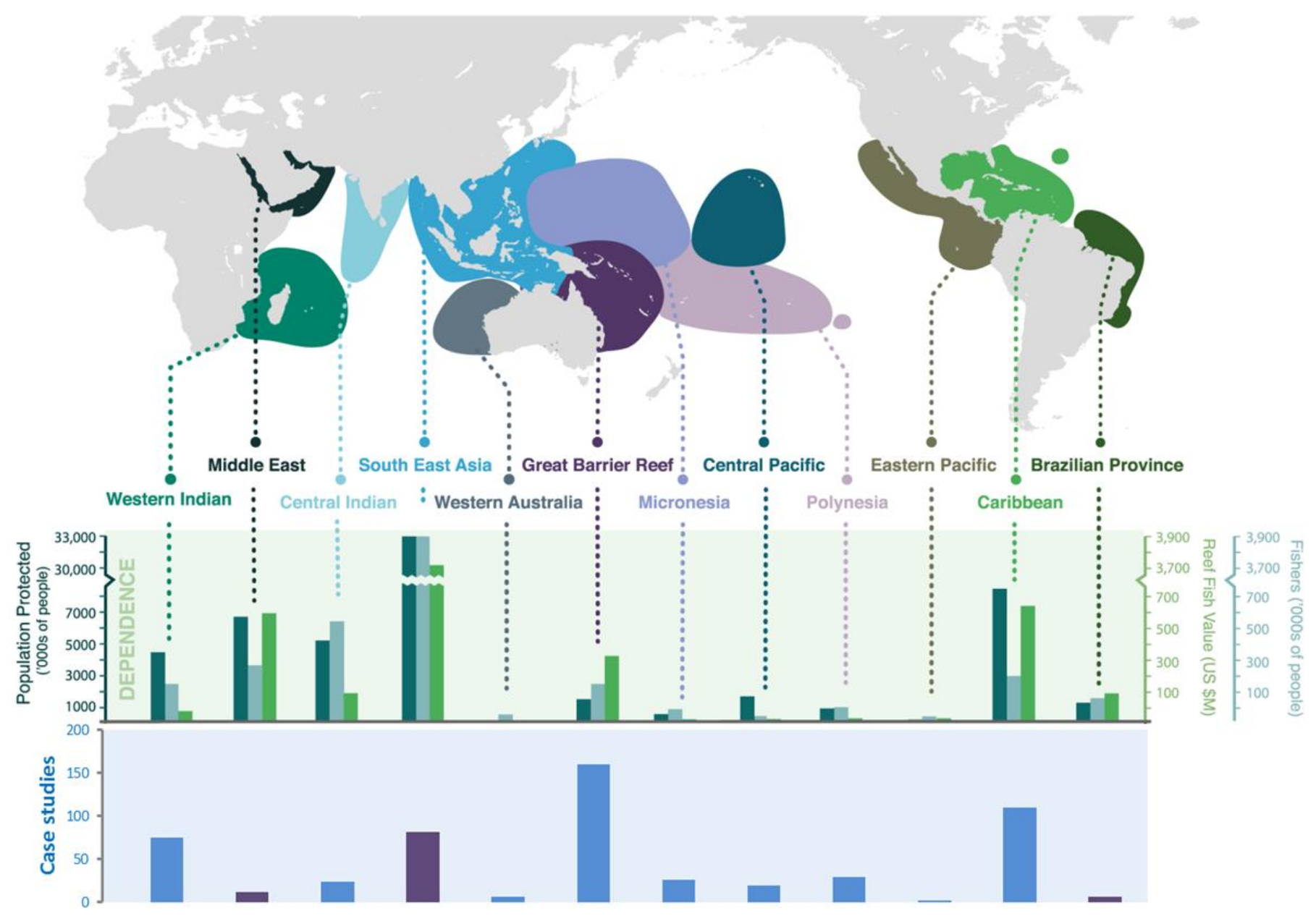

Figure 8: Regional dependence, by ocean province (OP), on ecosystem services and number of case studies per ocean province, modified from (Pendleton et al., 2016a). For case studies, purple OPs contain proportionally less case studies than their share of ecosystem services 


\section{Discussion}

\subsection{The literature focuses disproportionately on maintaining the ecological status quo}

The literature has focused disproportionately on efforts to hold the ecological line for coral reefs with more than $60 \%$ of studies focused on mitigate or protect, and less on helping people and coral ecosystems in a future in which the natural world will look quite different. Considerable scientific effort has gone into designing and effectiveness of MPAs, identification of sites and refugia, and managing fishing pressure and other environmental stressors. On the other hand, very little work has focused on repair measures that are more active management strategies aimed at rebuilding coral extent and ecosystem services after disturbances. Future research efforts need to focus on the effectiveness of repair strategies. Assisting the evolution of coral reefs to sustain them in a changing climate is in its early stage of development. In addition to the prohibitive cost of these techniques (Bayraktarov et al., 2016), ethical issues persists. Still, some argue that assisting evolution can be included in coral reefs restoration (van Oppen et al., 2017).

Despite the growing focus on adaptation in the climate change literature (Füssel and Klein, 2006), this new trend is not reflected in the coral reef literature with less than $25 \%$ of the studies focusing on adapt strategies. One reason for a lack of focus on human adaptation may be the ecological focus of the literature regarding coral reef management. There are two particularly striking gaps in the study of management strategies that relate to human populations dependent on reefs. First, migration of human population is mentioned as a sub-category of action but is not discussed in the 767 articles we reviewed. This is surprising given that this topic is well-covered in the general climate change adaptation literature (McLeman and Smit, 2006) and given that some coral reefs are located in low-lying islands particularly exposed to sea-level rise. Second, the issue of using indigenous knowledge for management under climate change was also barely touched on despite its important role for management (Veland et al., 2013). There are two possible explanations for the lack of coverage in the literature on these management strategies. It is possible that these are research frontiers that will be explored in the future. Alternatively, even though we reviewed 767 papers to identify management actions, we may have missed important contributions.

While numerous studies (e.g. Gattuso et al. (2015)) argue for a reduction of GHG emissions since the effectiveness of all other management strategies will depend on our success at stabilizing the climate around $1.5^{\circ} \mathrm{C}$ or $2^{\circ} \mathrm{C}$ of warming, the most optimistic emission pathway scenario will already lead to high impacts for coral reefs (Frieler et al., 2012). Reducing GHG emissions is now a matter of politics and not of science since the $1.5^{\circ} \mathrm{C}$ target is written in the article 2 (a) of the Paris Agreement (UNFCCC, 2015), and given that dealing with local anthropogenic threats is already well studied (Ateweberhan et al., 2013; Kroon et al., 2014; Magris et al., 2015). It is therefore crucial to move away from maintaining the status quo (Hughes et al., 2017) and to scientifically explore a full suite of solutions, including repair strategies, adaptation to the loss of ecosystem services and to explore combinations of these solutions. 


\subsection{The literature is not addressing many places where coral reefs and people are threatened}

Current scientific efforts do not target the full range of countries where coral reefs are located, including many places where corals and people are at risk of GEC. Most of the case studies examined are conducted in developed countries, and particularly Australia and the United States, which parallels their disproportional share of scientific contribution on biodiversity conservation in Oceania (Kingsford et al., 2009) and in general (Di Marco et al., 2017; Falkenberg and Tubb, 2017). It is important to note that there could be a bias in our analysis towards English speaking countries because only international peer reviewed journals in English are included in this review (Falkenberg and Tubb, 2017). There are few studies on coral reef management effectiveness for areas like South-East Asia, which has the highest dependence on coral reefs and also contains the highest coral diversity (Veron et al., 2015). South-East Asia, Brazil and the Middle East are all areas for which more scientific effort is needed to understand the human and ecological dimensions of coral reef management in the face of GEC.

The literature also reveals a tremendous patchiness in the distribution of human capacity to study the effectiveness and consequences of coral reef management actions to deal with GEC. Forty-two coral reef countries and territories were completely unrepresented in the affiliations of authors in these peer reviewed studies. The implications of such concentrations of authors at institutions in high income countries, studying coral reefs in other countries, are not clear. This aspect of research needs serious consideration given the disproportionate vulnerability of developing countries to the effects of GEC on coral reefs (Burke et al., 2011; Wolff et al., 2015) and given the fact that 26 developing countries and territories containing coral reefs also do not have case studies.

\section{Conclusions}

We refined a typology of management strategies in order to review the comprehensiveness of scientific investigation into the effectiveness and consequences of coral reef management in the face of GEC. The typology also reveals that management strategies differ along two key dimensions: 1) whether they seek to maintain an environmental status quo or accept environmental change and 2) whether they focus on ecological and environmental aspects or human aspects of coral reef social-ecological systems. Few studies examine a broad suite of ecological and human oriented approaches. The typology discussed in this article could also be applied to other SES, both marine and terrestrial. Typologies like the one refined and presented here can assist in conveying scientific knowledge to decision-makers (e.g. IPBES or IPCC) and building a dialogue between scientists, managers, and decision-makers around the issues of global environmental change in general (Moser, 2010) and of coral reefs in particular (Crosby et al., 2002). It is the role of managers and decision-makers to appropriate this knowledge and produce decisions and management plans that will shape the future of coral reefs and people who depend on them. We hope 
to have clarified the range of potential management strategies to respond to these threats so that this work can be used as a first step in the identification and appraisal of actions, for instance in adaptive management frameworks (Birgé et al., 2016).

If managers are to be able to weigh the tradeoffs of the full suite of management options, scientific efforts need to be broadened across management options and also across coral reef geographies. The existence of barriers and limits to the effectiveness of existing management strategies needs to be recognized (Barnett et al., 2015; Feagin et al., 2010). Yet, we find that the scientific literature has not focused enough on "adapt" and "repair" management strategies that deal with the inevitable impacts of GEC. It is clear that current research is biased towards developed countries (especially Australia and the United States) and towards "protect" management strategies. A re-organization of scientific research on the subject is needed. Under-studied geographic locations including developing countries in South-East Asia, in the Western Indian Ocean, in the Middle East, in the Pacific, and in the Caribbean should be the focus of future research. New research is also needed on adaptation of people who depend on coral reefs. Future research should attempt to study multiple strategies at the same time to understand tradeoffs and synergies between management strategies. This reorganization is possible without undermining scientific efforts on traditional topics of protecting biodiversity thanks to the increase in the number of papers and scientists working on this field.

\section{Acknowledgments}

This work was supported by the "Laboratoire d'Excellence" LabexMER (ANR-10-LABX-19) and co-funded by a grant from the French government under the program "Investissements d'Avenir", and by a grant from the Regional Council of Brittany. We declare no conflict of interest. We thank Jean-Pierre Gattuso and Alexandre Magnan for their input on designing the typology. We acknowledge Morgane Le Gall and Bibliothèque La Perouse, Ifremer for her help in the data collection and treatment. We also acknowledge Claire Bissery and Didier Dacunha-Castelle for their help in designing the statistical analyses. Figures 2 and 8 are reproduced with the permission of Vanessa Gonzalez-Ortiz.

\section{References}

Arkema, K.K., Guannel, G., Verutes, G., Wood, S. a., Guerry, A., Ruckelshaus, M., Kareiva, P., Lacayo, M., Silver, J.M., 2013. Coastal habitats shield people and property from sea-level rise and storms. Nat. Clim. Chang. 3, 913-918. doi:10.1038/nclimate1944

Ateweberhan, M., Feary, D.A., Keshavmurthy, S., Chen, A., Schleyer, M.H., Sheppard, C.R.C., 2013. Climate change impacts on coral reefs: synergies with local effects, possibilities for acclimation, and management implications. Mar. Pollut. Bull. 74, 526-539. doi:10.1016/j.marpolbul.2013.06.011

Barnett, J., Evans, L.S., Gross, C., Kiem, A.S., Kingsford, R.T., Palutikof, J.P., Pickering, C.M., Smithers, S.G., 2015. From barriers to limits to climate change adaptation: path dependency and the speed of 
change. Ecol. Soc. 20, art5. doi:10.5751/ES-07698-200305

Bayraktarov, E., Saunders, M.I., Abdullah, S., Mills, M., Beher, J., Possingham, H.P., Mumby, P.J., Lovelock, C.E., 2016. The cost and feasibility of marine coastal restoration. Ecol. Appl. 26, 10551074. doi:10.5061/dryad.rc0jn

Biagini, B., Bierbaum, R., Stults, M., Dobardzic, S., McNeeley, S.M., 2014. A typology of adaptation actions: A global look at climate adaptation actions financed through the Global Environment Facility. Glob. Environ. Chang. 25, 97-108. doi:10.1016/j.gloenvcha.2014.01.003

Birgé, H.E., Allen, C.R., Garmestani, A.S., Pope, K.L., 2016. Adaptive management for ecosystem services. J. Environ. Manage. 183, 343-352. doi:10.1016/j.jenvman.2016.07.054

Bozec, Y.-M., O'Farrell, S., Bruggemann, J.H., Luckhurst, B.E., Mumby, P.J., 2016. Tradeoffs between fisheries harvest and the resilience of coral reefs. Proc. Natl. Acad. Sci. 113, 201601529. doi:10.1073/pnas.1601529113

Brander, L.M., Rehdanz, K., Tol, R.S.J., Van Beukering, P.J.H., 2012. The Economic Impact of Ocean Acidification on Coral Reefs. Clim. Chang. Econ. 3, 1250002. doi:10.1142/S2010007812500029

Burke, L., Reytar, K., Spalding, M., Perry, A., 2011. Reefs at risk Revisited, World Resources Institute. Washington, D.C. doi:10.1016/0022-0981(79)90136-9

Cinner, J.E., Huchery, C., Darling, E.S., Humphries, A.T., Graham, N.A.J., Hicks, C.C., Marshall, N., McClanahan, T.R., 2013. Evaluating social and ecological vulnerability of coral reef fisheries to climate change. PLoS One 8, e74321. doi:10.1371/journal.pone.0074321

Cinner, J.E., Pratchett, M.S., Graham, N.A.J., Messmer, V., Fuentes, M.M.P.B., Ainsworth, T., Ban, N., Bay, L.K., Blythe, J., Dissard, D., Dunn, S., Evans, L., Fabinyi, M., Fidelman, P., Figueiredo, J., Frisch, A.J., Fulton, C.J., Hicks, C.C., Lukoschek, V., Mallela, J., Moya, A., Penin, L., Rummer, J.L., Walker, S., Williamson, D.H., 2016. A framework for understanding climate change impacts on coral reef social-ecological systems. Reg. Environ. Chang. 16, 1133-1146. doi:10.1007/s10113-015-0832-z

Crosby, M.P., Brighouse, G., Pichon, M., 2002. Priorities and strategies for addressing natural and anthropogenic threats to coral reefs in Pacific Island Nations. Ocean Coast. Manag. 45, 121-137. doi:10.1016/S0964-5691(02)00051-0

Di Marco, M., Chapman, S., Althor, G., Kearney, S., Besancon, C., Butt, N., Maina, J.M., Possingham, H.P., Rogalla von Bieberstein, K., Venter, O., Watson, J.E.M., 2017. Changing trends and persisting biases in three decades of conservation science. Glob. Ecol. Conserv. 10, 32-42. doi:10.1016/j.gecco.2017.01.008

Duarte, C.M., Losada, I.J., Hendriks, I.E., Mazarrasa, I., Marbà, N., 2013. The role of coastal plant communities for climate change mitigation and adaptation. Nat. Clim. Chang. 3, 961-968. doi:10.1038/nclimate1970

Ekstrom, J.A., Suatoni, L., Cooley, S.R., Pendleton, L.H., Waldbusser, G.G., Cinner, J.E., Ritter, J., Langdon, C., van Hooidonk, R., Gledhill, D., Wellman, K., Beck, M.W., Brander, L.M., Rittschof, D., Doherty, C., Edwards, P.E.T., Portela, R., 2015. Vulnerability and adaptation of US shellfisheries to ocean acidification. Nat. Clim. Chang. 5, 207-214. doi:10.1038/nclimate2508

Engle, N.L., 2011. Adaptive capacity and its assessment. Glob. Environ. Chang. 21, 647-656. doi:10.1016/j.gloenvcha.2011.01.019

Evans, L., Fidelman, P., Hicks, C., Morgan, C., Perry, A.L., Tobin, R., 2016. Structural and psycho-social limits to climate change adaptation in the Great Barrier reef 1-17. doi:10.1371/journal.pone.0150575

Fadli, N., Campbell, S.J., Ferguson, K., Keyse, J., Rudi, E., Riedel, A., Baird, A.H., 2012. The role of habitat creation in coral reef conservation: a case study from Aceh, Indonesia. Oryx 46, 501-507. doi:10.1017/S0030605312000142

Falkenberg, L.J., Tubb, A., 2017. Economic effects of ocean acidification: Publication patterns and directions for future research. Ambio. doi:10.1007/s13280-017-0895-9 
Feagin, R.A., Mukherjee, N., Shanker, K., Baird, A.H., Cinner, J., Kerr, A.M., Koedam, N., Sridhar, A., Arthur, R., Jayatissa, L.P., Lo Seen, D., Menon, M., Rodriguez, S., Shamsuddoha, M., DahdouhGuebas, F., 2010. Shelter from the storm? Use and misuse of coastal vegetation bioshields for managing natural disasters. Conserv. Lett. 3, 1-11. doi:10.1111/j.1755-263X.2009.00087.x

Fine, M., Gildor, H., Genin, A., 2013. A coral reef refuge in the Red Sea. Glob. Chang. Biol. 19, 3640-3647. doi:10.1111/gcb.12356

Frieler, K., Meinshausen, M., Golly, A., Mengel, M., Lebek, K., Donner, S.D., Hoegh-Guldberg, O., 2012. Limiting global warming to $2{ }^{\circ} \mathrm{C}$ is unlikely to save most coral reefs. Nat. Clim. Chang. 3, 165-170. doi:10.1038/nclimate1674

Füssel, H.-M., Klein, R.J.T., 2006. Climate Change Vulnerability Assessments: An Evolution of Conceptual Thinking. Clim. Change 75, 301-329. doi:10.1007/s10584-006-0329-3

Gattuso, J.-P., Magnan, A., Billé, R., Cheung, W.W.L., Howes, E.L., Joos, F., Allemand, D., Bopp, L., Cooley, S.R., Eakin, C.M., Hoegh-Guldberg, O., Kelly, R.P., Portner, H.-O., Rogers, a. D., Baxter, J.M., Laffoley, D., Osborn, D., Rankovic, A., Rochette, J., Sumaila, U.R., Treyer, S., Turley, C., 2015. Contrasting futures for ocean and society from different anthropogenic $\mathrm{CO} 2$ emissions scenarios. Science (80-. ). 349. doi:http://dx.doi.org/10.1126/science.aac4722

Green, A.L., Fernandes, L., Almany, G., Abesamis, R., McLeod, E., Aliño, P.M., White, A.T., Salm, R., Tanzer, J., Pressey, R.L., 2014. Designing Marine Reserves for Fisheries Management, Biodiversity Conservation, and Climate Change Adaptation. Coast. Manag. 42, 143-159. doi:10.1080/08920753.2014.877763

Hilborn, R., 2016. Marine biodiversity needs more than protection. Nat. News 535, 234-236. doi:10.1038/535224a

Hinkel, J., 2011. "Indicators of vulnerability and adaptive capacity": Towards a clarification of the science-policy interface. Glob. Environ. Chang. 21, 198-208. doi:10.1016/j.gloenvcha.2010.08.002

Hinkel, J., Bisaro, A., 2015. A review and classification of analytical methods for climate change adaptation. Wiley Interdiscip. Rev. Clim. Chang. 6, 171-188. doi:10.1002/wcc.322

Hoegh-Guldberg, O., Cai, R., Poloczanska, E.S.S., Brewer, P.G.G., Sundby, S., Hilmi, K., Fabry, V.J.J., Jung, S., 2014. The Ocean, in: Press, C.U. (Ed.), Climate Change 2014: Impacts, Adaptation, and Vulnerability. Part B: Regional Aspects. Contribution of Working Group II to the Fifth Assessment Report of the Intergovernmental Panel on Climate Change. Cambridge University Press, Cambridge, United Kingdom and New York, NY, USA, pp. 1655-1731.

Hughes, S., Yau, A., Max, L., Petrovic, N., Davenport, F., Marshall, M., McClanahan, T.R., Allison, E.H., Cinner, J.E., 2012. A framework to assess national level vulnerability from the perspective of food security: The case of coral reef fisheries. Environ. Sci. Policy 23, 95-108. doi:10.1016/j.envsci.2012.07.012

Hughes, T.P., Barnes, M.L., Bellwood, D.R., Cinner, J.E., Cumming, G.S., Jackson, J.B.C., Kleypas, J., Leemput, I.A. van de, Lough, J.M., Morrison, T.H., Palumbi, S.R., Nes, E.H. Van, Scheffer, M., 2017. Coral reefs in the Anthropocene. Nature in press. doi:10.1038/nature22901

IPCC, 2014. Summary for Policy Makers. Clim. Chang. 2014 Impacts, Adapt. Vulnerability - Contrib. Work. Gr. II to Fifth Assess. Rep. 1-32. doi:10.1016/j.renene.2009.11.012

Jones, H.P., Hole, D.G., Zavaleta, E.S., 2012. Harnessing nature to help people adapt to climate change. Nat. Clim. Chang. 2, 504-509. doi:10.1038/nclimate1463

Keller, B.D., Gleason, D.F., McLeod, E., Woodley, C.M., Airamé, S., Causey, B.D., Friedlander, A.M., Grober-Dunsmore, R., Johnson, J.E., Miller, S.L., Steneck, R.S., 2009. Climate Change, Coral Reef Ecosystems, and Management Options for Marine Protected Areas. Environ. Manage. 44, 10691088. doi:10.1007/s00267-009-9346-0

Kelly, R.P., Foley, M.M., Fisher, W.S., Feely, R. a, Halpern, B.S., Waldbusser, G.G., Caldwell, M.R., 2011. Oceans. Mitigating local causes of ocean acidification with existing laws. Science 332, 1036-1037. 
doi:10.1126/science.1203815

Kingsford, R.T., Watson, J.E.M., Lundquist, C.J., Venter, O., Hughes, L., Johnston, E.L., Atherton, J., Gawel, M., Keith, D.A., Mackey, B.G., Morley, C., Possingham, H.P., Raynor, B., Recher, H.F., Wilson, K.A., 2009. Major Conservation Policy Issues for Biodiversity in Oceania. Conserv. Biol. 23, 834-840. doi:10.1111/j.1523-1739.2009.01287.x

Kroon, F.J., Schaffelke, B., Bartley, R., 2014. Informing policy to protect coastal coral reefs: Insight from a global review of reducing agricultural pollution to coastal ecosystems. Mar. Pollut. Bull. 85, 33-41. doi:10.1016/j.marpolbul.2014.06.003

Lubchenco, J., Palumbi, S.R., Gaines, S.D., Andelman, S., 2003. Plugging a Hole in the Ocean: Emerging Science of Marine Reserves. Ecol. Appl. 13, 3-7.

MacNeil, M.A., Graham, N.A.J., Cinner, J.E., Dulvy, N.K., Loring, P.A., Jennings, S., Polunin, N.V.C., Fisk, A.T., McClanahan, T.R., 2010. Transitional states in marine fisheries: adapting to predicted global change. Philos. Trans. R. Soc. B Biol. Sci. 365, 3753-3763. doi:10.1098/rstb.2010.0289

Magnan, A.K., Schipper, E.L.F., Burkett, M., Bharwani, S., Burton, I., Eriksen, S., Gemenne, F., Schaar, J., Ziervogel, G., 2016. Addressing the risk of maladaptation to climate change. Wiley Interdiscip. Rev. Clim. Chang. 7, 646-665. doi:10.1002/wcc.409

Magris, R.A., Heron, S.F., Pressey, R.L., 2015. Conservation Planning for Coral Reefs Accounting for Climate Warming Disturbances. PLoS One 10, e0140828. doi:10.1371/journal.pone.0140828

McLeman, R., Smit, B., 2006. Migration as an adaptation to climate change. Clim. Change 76, 31-53. doi:10.1007/s10584-005-9000-7

Mcleod, E., Anthony, K.R.N., Andersson, A., Beeden, R., Golbuu, Y., Kleypas, J., Kroeker, K., Manzello, D., Salm, R. V, Schuttenberg, H., Smith, J.E., 2013. Preparing to manage coral reefs for ocean acidification: lessons from coral bleaching. Front. Ecol. Environ. 11, 20-27. doi:10.1890/110240

Millenium Ecosystem Assessment, 2005. Ecosystems and Human Well-Being Synthesis. Washington, D.C.

Moser, S.C., 2010. Now more than ever: The need for more societally relevant research on vulnerability and adaptation to climate change. Appl. Geogr. 30, 464-474. doi:10.1016/j.apgeog.2009.09.003

Mumby, P.J., Anthony, K.R.N., 2015. Resilience metrics to inform ecosystem management under global change with application to coral reefs. Methods Ecol. Evol. 6, 1088-1096. doi:10.1111/2041210X.12380

Pendleton, L., Comte, A., Langdon, C., Ekstrom, J.A., Cooley, R., Suatoni, L., Beck, M.W., Brander, L.M., Burke, L., Cinner, E., Doherty, C., Edwards, P.E.T., Gledhill, D., Jiang, L., Hooidonk, R.J. Van, Teh, L., Waldbusser, G.G., Ritter, J., 2016a. Coral Reefs and People in a High-CO 2 World : Where Can Science Make a Difference to People ? PLoS One 11, 1-21. doi:10.1371/journal.pone.0164699

Pendleton, L., Hoegh-Guldberg, O., Langdon, C., Comte, A., 2016b. Multiple Stressors and Ecological Complexity Require a New Approach to Coral Reef Research. Front. Mar. Sci. 3, 1-5. doi:10.3389/fmars.2016.00036

Ranger, N., Garbett-Shiels, S.-L., 2012. Accounting for a changing and uncertain climate in planning and policymaking today : lessons for developing countries. Clim. Dev. doi:10.1080/17565529.2012.732919

Rau, G.H., McLeod, E.L., Hoegh-Guldberg, O., 2012. The need for new ocean conservation strategies in a high-carbon dioxide world. Nat. Clim. Chang. 2, 720-724. doi:10.1038/nclimate1555

Riebesell, U., Gattuso, J.-P., 2015. Lessons learned from ocean acidification research. Nat. Clim. Chang. 5, 12-14. doi:10.1038/nclimate2456

Roberts, C.M., McClean, C.J., Veron, J.E.N., Hawkins, J.P., Allen, G.R., McAllister, D.E., Mittermeier, C.G., Schueler, F.W., Spalding, M.D., Wells, F., Vynne, C., Werner, T.B., 2002. Marine Biodiversity Hotspots and Conservation Priorities for Tropical Reefs. Science (80-. ). 295, 1280-1284. doi:10.1126/science.1067728

Roberts, C.M., O'Leary, B.C., McCauley, D.J., Cury, P.M., Duarte, C.M., Lubchenco, J., Pauly, D., Sáenz- 
Arroyo, A., Sumaila, U.R., Wilson, R.W., Worm, B., Castilla, J.C., 2017. Marine reserves can mitigate and promote adaptation to climate change. Proc. Natl. Acad. Sci. 201701262.

doi:10.1073/pnas.1701262114

Schipper, E.L.F., 2006. Conceptual history of adaptation in the UNFCCC process. Rev. Eur. Community Int. Environ. Law 15, 82-92. doi:10.1111/j.1467-9388.2006.00501.x

Teh, L.S.L., Teh, L.C.L., Sumaila, U.R., 2013. A global estimate of the number of coral reef fishers. PLoS

One 8. doi:10.1371/journal.pone.0065397

The World Bank, 2017. World Development Indicators.

Tulloch, V.J.D., Tulloch, A.I.T., Visconti, P., Halpern, B.S., Watson, J.E.M., Evans, M.C., Auerbach, N.A., Barnes, M., Beger, M., Chadès, I., Giakoumi, S., McDonald-Madden, E., Murray, N.J., Ringma, J., Possingham, H.P., 2015. Why do We map threats? Linking threat mapping with actions to make better conservation decisions. Front. Ecol. Environ. 13, 91-99. doi:10.1890/140022

UNEP-WCMC, WorldFish Centre, WRI, T., 2010. Global distribution of warm-water coral reefs, compiled from multiple sources including the Millennium Coral Reef Mapping Project. Version 1.3. Includes contributions from IMaRS-USF and IRD (2005), IMaRS-USF (2005) and Spalding et al. (2001).

UNFCCC, 2015. Adoption of the Paris Agreement. Rep. No. FCCC/CP/2015/L.9/Rev.132. doi:FCCC/CP/2015/L.9/Rev.1

van Oppen, M., Gates, R., Blackall, L., Cantin, N., Chakravarti, L., Chan, W., Cormick, C., Crean, A., Damjanovic, K., Epstein, H., Harrison, P., Jones, T., Miller, M., Pears, R., Peplow, L., Raftos, D., Schaffelke, B., K, S., Torda, G., Wachenfeld, D., Weeks, A., Putnam, H., 2017. Shifting paradigms in restoration of the world's coral reefs. Glob. Chang. Biol. 1-12. doi:10.1111/gcb.13647

van Oppen, M.J.H., Oliver, J.K., Putnam, H.M., Gates, R.D., 2015. Building coral reef resilience through assisted evolution. Proc. Natl. Acad. Sci. U. S. A. 112, 2307-2313. doi:10.1073/pnas.1422301112

Veland, S., Howitt, R., Dominey-Howes, D., Thomalla, F., Houston, D., 2013. Procedural vulnerability: Understanding environmental change in a remote indigenous community. Glob. Environ. Chang. 23, 314-326. doi:10.1016/j.gloenvcha.2012.10.009

Veron, J., Stafford-Smith, M., DeVantier, L., Turak, E., 2015. Overview of distribution patterns of zooxanthellate Scleractinia. Front. Mar. Sci. 1, 1-19. doi:10.3389/fmars.2014.00081

Wilby, R.L., Dessai, S., 2010. Robust adaptation to climate change. Weather 65, 180-185. doi:10.1002/wea.543

Wolff, N.H., Donner, S.D., Cao, L., Iglesias-Prieto, R., Sale, P.F., Mumby, P.J., 2015. Global inequities between polluters and the polluted: climate change impacts on coral reefs. Glob. Chang. Biol. 21, 3982-3994. doi:10.1111/gcb.13015 


\section{Supplementary Materials}

SM1: Four equations were used in Web of Science and Scopus on the period 1990-2016 to retrieve peer reviewed research articles on coral reefs in particular and on climate change in general

SM2: Differences between the typology developed by Gattuso et al. (2015) and the one adapted here for coral reefs SES

SM3: Exhaustive list and description of management actions discussed in the literature

Figure S1: Authors affiliations per country for the four categories of management strategies (A-D)

Figure S2: Case studies per country for the four categories of management strategies $(\mathrm{E}-\mathrm{H})$ 
SM1: Four equations were used in Web of Science and Scopus on the period 1990-2016 to retrieve peer reviewed research articles for coral reefs:

Equation 1:

("chang* climat" OR "climat* chang*" OR "climat* impact*" OR "ocean* acidification" OR "ocean warming")) AND TOPIC: ("coral* reef*" OR coral OR corals OR reef*) AND TOPIC: (mitigat* OR "manage* option*" OR "manage* action*")

Equation 2:

("chang* climat" OR "climat* chang*" OR "climat* impact*" OR "ocean* acidification" OR "ocean warming") AND TOPIC: ("coral* reef*" OR coral OR corals OR reef*) AND TOPIC: (polic* OR "threat* manag*" OR "impact* manag*" OR mitigat* OR "conserv* manag*" OR "vulnerab* manag*")

Equation 3:

("climat* chang*" OR "climat* impact*" OR "ocean* acidification" OR "ocean warming") AND TOPIC: ("coral* reef*" OR coral* OR reef*) AND TOPIC: (polic* OR "threat* manag*" OR "impact* manag*" OR mitigat* OR "conserv* manag*" OR "vulnerab* manag*" OR restorat*)

Equation 4:

("chang* climat" OR "climat* chang*" OR "climat* impact*" OR "ocean* acidification" OR "ocean warming") AND TOPIC: ("coral* reef*" OR coral OR corals OR reef*) AND TOPIC: (recovery OR mitigat* OR manag* OR monitor* OR stop*) AND TOPIC: (framework OR tool* OR plan OR plans OR planning OR model OR models OR "key* driver*" OR "environ* driver*" OR protocol*)

Four equations were used in Web of Science and Scopus on the period 1990-2016 to retrieve peer reviewed research articles for the whole field of climate change:

Equation 1:

("chang* climat" OR "climat* chang*" OR "climat* impact*" OR "ocean* acidification" OR "ocean warming")) AND TOPIC: (mitigat* OR "manage* option*" OR "manage* action*")

Equation 2:

("chang* climat" OR "climat* chang*" OR "climat* impact*" OR "ocean* acidification" OR "ocean warming") AND TOPIC: (polic* OR "threat* manag*" OR "impact* manag*" OR mitigat* OR "conserv* manag*" OR "vulnerab* manag*")

Equation 3:

("climat* chang*" OR "climat* impact*" OR "ocean* acidification" OR "ocean warming") AND TOPIC: (polic* OR "threat* manag*" OR "impact* manag*" OR mitigat* OR "conserv* manag*" OR "vulnerab* manag*" OR restorat*)

Equation 4:

("chang* climat" OR "climat* chang*" OR "climat* impact*" OR "ocean* acidification" OR "ocean warming") AND TOPIC: (recovery OR mitigat* OR manag* OR monitor* OR stop*) AND TOPIC: (framework OR tool* OR plan OR plans OR planning OR model OR models OR "key* driver*" OR "environ* driver*" OR protocol*) 
SM2: Differences (orange boxes) between (A) the typology developed by Gattuso et al. (2015) and (B) the one adapted here for coral reefs SES

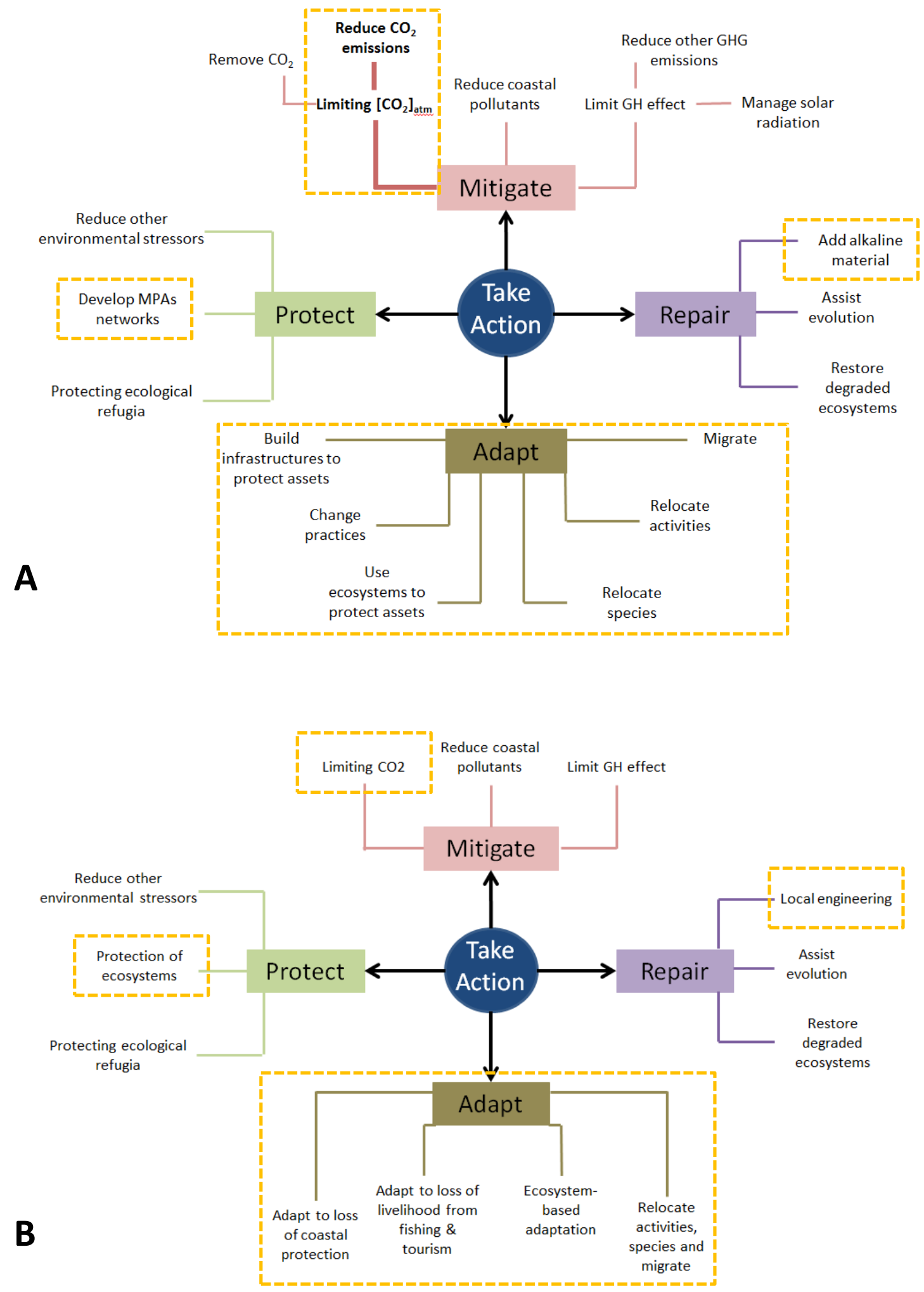


SM3: exhaustive list of management actions discussed in the literature

\section{Mitigate}

\subsection{Limiting $\mathrm{CO}_{2}$}

Reducing greenhouse gases, and especially $\mathrm{CO}_{2}$, is the first response to the impacts of GEC on coral reefs (Billé et al., 2013; Gattuso et al., 2015). $\mathrm{CO}_{2}$ is the GHG most important for coral reefs, since it contributes both to sea temperature rise and ocean acidification, while the other GHG only contribute to sea temperature rise. However, it is largely outside the capacity and the mandate of coral reefs managers and local decision-makers. Several big emitters, including first Australia, the United States, but also China and Japan are obtaining benefits from coral reefs and have the capacity to reduce global levels of $\mathrm{CO}_{2}$ emissions and the political power to influence climate negotiations. There are several ways to limit $\mathrm{CO}_{2}$ by either reducing its emissions from polluting industries and change in land-use, or by directly removing it from the atmosphere. Carbon sequestration in marine and coastal ecosystems such as mangroves and seagrasses also has the potential to remove large quantities of $\mathrm{CO}_{2}$ from the atmosphere. Other innovative strategies exist to sequester more carbon into the ocean through increasing the storage life of $\mathrm{CO}_{2}$ in the ocean in the form of organic matter for instance (Rau et al., 2012).

\subsection{Reducing the effects of other $\mathrm{GH}$}

Reducing the amount of GHG is important to prevent warming of the ocean that can trigger mass bleaching events (Adam et al., 2015; Billé et al., 2013). Reduction of greenhouse gases requires a global effort and is largely beyond the means of many coral reef dependent countries. The benefit of reducing GHG and the actions available to do so have been covered extensively in the literature (for example Harrould-Kolieb and Herr, 2012; Wolff et al., 2015). In addition, geoengineering strategies exist: solar radiation management (SRM) and carbon management. SRM does not address the root causes of the problem and creates and may actually lead to its increase by des-incentivizing the reduction of $\mathrm{CO}_{2}$ emissions (Williamson and Bodle, 2016); therefore it is not an appropriate strategy for coral reefs ecosystems (Crabbe, 2009). Carbon dioxide removal addresses both thermal stress and ocean acidification, thus being an interesting avenue for future development, including ecosystem-based sequestration of $\mathrm{CO}_{2}$ which is readily available and provides multiple ecosystem services benefits (e.g. Serafy et al. 2015).

\subsection{Coastal pollution}

Coastal pollution coming from the land is a major issue that needs to be dealt with to reduce pollution on coral reefs (Brodie and Pearson, 2016). Coastal pollution contributes to global threats to coral reefs. Watershed management is an important tool to reduce land-based coastal pollution (Keller et al., 2009; Mumby and Steneck, 2008). Sediment, sewage, and agricultural waste runoffs effects are diffuse sources of pollutants that can be best managed at the watershed level. Watershed management could be effective but a lot of concertation is needed to manage coastal pollution because of the high number of conflicting interests and the complexity of governing bodies and socio-ecological systems (Lebel, 2012). 
To prevent coastal pollution from the agricultural sector, a suite of management tools have been identified (Kroon et al., 2014). Fertilizer use can be reduced since nitrogen and phosphorous lead to eutrophication of coastal waters and modify the ocean pH (Anthony et al., 2015). Antisprawl land-use plans (Anthony et al., 2015; Kelly et al., 2011) and preventing deforestation would limit runoff to the sea (Maynard et al., 2015). Infrastructure and impacts from the industry can be improved, including using settling ponds to deal with effluent, improving water treatment facilities, and using storm water surge prevention equipment for example (Ateweberhan et al., 2013; Kelly et al., 2011; Kroon et al., 2014). Coastal pollution may also come from marine activities. To reduce these impacts, it is possible to control ballast water (Burke et al., 2011; Mumby and Steneck, 2008), to improve waste management at ports, to modify shipping lanes, or to regulate oil and gas activities offshore (Burke et al., 2011).

Restoring wetlands and buying back agricultural land may also improve water quality surrounding reef areas (Burke et al., 2011; Kroon et al., 2014; Maynard et al., 2015; Mumby and Steneck, 2008). Watershed restoration has been proposed as a solution to reduce erosion that contributes to coastal pollution (Shelton and Richmond, 2016). These techniques include the use of sediment traps, avoiding drainage and erosion, creating riparian buffers through ecological restoration, and stabilizing stream banks (Burke et al., 2011; Maynard et al., 2015).

\begin{tabular}{|l|l|}
\hline Mitigate & \\
\hline Limiting $\mathrm{CO}_{2}$ & reduce $\mathrm{CO}_{2}$ emissions \\
\hline & remove $\mathrm{CO}_{2}$ from atmosphere \\
\hline & increase photosynthesis through ocean fertilization \\
\hline & carbon sequestration in marine ecosystems \\
\hline & increase storage life of organic matter in ocean \\
\hline Reducing the effects of GH & store agricultural crop waste in ocean \\
\hline & limit warming through reducing other GHG \\
\hline & limit warming through Solar Radiation Management \\
\hline Coastal pollution & $\begin{array}{l}\text { enforce existing federal emissions limits for pollutants such as nitrogen } \\
\text { oxide and sulfur oxide }\end{array}$ \\
\hline & manage watershed \\
\hline & improve management of catchment \\
\hline & manage agriculture pollution \\
\hline & reduce economic livestock numbers \\
\hline & control tillage \\
\hline & reduce fertilizer use \\
\hline & manage livestock waste \\
\hline & control grazing \\
\hline & reduce point source pollution from industry and agriculture \\
\hline & plan land-use against sprawl \\
\hline & control coastal development activities \\
\hline &
\end{tabular}




\begin{tabular}{|l|l|}
\hline & reduce sedimentation \\
\hline & use sediment traps \\
\hline & avoid drainage and erosion \\
\hline & direct effluent to settling ponds \\
\hline & route discharge offshore \\
\hline & avoid dredging and landfilling \\
\hline & alter zoning provisions and general plans to safeguard waters \\
\hline & improve water quality by limiting deforestation \\
\hline & create coastal and riparian buffers \\
\hline & improve onsite water treatment facilities \\
\hline & stabilize stream banks \\
\hline & restore vegetation at land-water intersections \\
\hline & control transport such as sediment trapping dams \\
\hline & reduce industrial pollution \\
\hline & upgrade sewage treatment \\
\hline & reduce runoff from mines \\
\hline & monitor and limit precipitation runoff and associated pollutants \\
\hline & prevent storm water surge with holding tanks \\
\hline & treat and control ballast water \\
\hline & improve waste management at ports and marinas \\
\hline & regulate and prevent access to offshore oil and gas activities \\
\hline & designate safe shipping lanes \\
\hline &
\end{tabular}

\section{Protect}

\subsection{Reduce local stressors to improve resilience}

The resilience of coral reefs is determined by the amount of local and global factors that threaten them (Scheffer, 2015). Reducing local stressors is essential to improve the resilience of coastal ecosystems and allow the continued provision of ecosystem services under climate change. Coastal pollution has already been addressed in the mitigation section, but other local threats can be managed, including fishing, recreation, trade in reefs products, and biological threats (e.g. starfish and invasive species).

Reducing fishing pressure could help delay the negative impacts of climate change and OA on reefs by improving their resilience (MacNeil et al., 2015). Large herbivorous fish, particularly grazers such as parrotfish are important to maintain resilience and promote the recovery of coral reefs after disturbances (Bozec et al., 2016; Hughes et al., 2007; McClanahan et al., 2009). Reducing the fishing pressure on herbivores is one of the most commonly cited measures to protect coral reefs (Anthony et al., 2015; Billé et al., 2013; Graham et al., 2013; MacNeil et al., 2010; Maynard et al., 2015; Mcleod et al., 2013; Rogers et al., 2015), a view that is shared by MPA managers (Hopkins et al., 2016). Other fishing 
restrictions include stopping destructive fishing practices (Anthony et al., 2015; Ateweberhan et al., 2013), and decreasing commercial and recreational efforts globally (Anthony et al., 2015; Ateweberhan et al., 2013; Rau et al., 2012). Actions can be taken on fishing gears by banning gear that targets ecologically important species, restricting the use of some gears, or encouraging the use of alternative gears to divert effort (Bozec et al., 2016; Graham et al., 2013; MacNeil et al., 2015, 2010). Finally, measures such as species restriction or access restriction may be useful to improve the resilience of the reefs (MacNeil et al., 2015). Fishing restrictions could also be timed after disturbances, where the abundance of large fish is critical for the recovery of reef systems (Graham et al., 2013).

Other stressors have to be taken into account to maintain and improve the resilience of coral reefs. Biological threats including Crown-of-Thorn Starfish (CoTS) can be managed (Anthony et al., 2015). Invasive species, including lionfish and invertebrates may benefit from climate change and disturb ecosystem functioning. Therefore they need to be controlled, for instance through culling efforts (Côté and Green, 2012; Grieve et al., 2016; Przeslawski et al., 2008). Coral diseases are rising and management tools to deal with this issue need to be developed (Page et al., 2009), including promotion of fish richness that seem to contribute to reduce the occurrence of diseases (Lamb et al., 2016). Regulations can be implemented to reduce trade in reef products and to prevent using reef materials for construction (Burke et al., 2011).

\subsection{Protection of ecosystems and associated ecosystems}

Marine Protected Areas (MPAs), specifically no-take marine reserves and networks of MPAs have been identified as a strategic tool to enhance the resilience of coral reefs to climate change (Hughes et al., 2003). The effectiveness of these measures to protect coral reefs against global environmental change is debated. MPAs have not been shown to protect coral reefs against the effect of rising temperature (Selig et al., 2012), but are linked to multiple factors of reefs resilience. Empirical evidence suggest that no-take reserves, while increasing fish abundance, does not improve the resilience of coral reefs or coral cover (Toth et al., 2014). From Bruno and Valdivia, (2016): "This interpretation is consistent with numerous local, regional, and global studies indicating that local protection, does not measurably lessen the impacts of ocean warming on coral populations". However, their importance may lie in their improvement of resilience and therefore on the recovery of coral reefs after disturbances such as bleaching events (Hughes et al., 2017; West and Salm, 2003). No-take marine reserves have been showed to increase coral cover in some parts of the world (Magdaong et al., 2014) and to mitigate the impacts of other external stressors such as floods (Olds et al., 2014) and diseases thanks to the prevention of physical damage from fishing (Lamb et al., 2015).

Protecting associated ecosystems can increase the resilience of coral reefs to $\mathrm{CO}_{2}$ (Ateweberhan et al., 2013; Burke et al., 2011; Green et al., 2014; Keller et al., 2009; Mcleod et al., 2013; Mumby and Steneck, 2008). These ecosystems include mangroves and seagrasses. Protecting associated ecosystems may yield co-benefits in terms of carbon sequestration and other ecosystem services that will be important in the face of climate change, including coastal protection services by mangroves (Das and Vincent, 2009). Mangroves provide shoreline protection and important habitat for commercially and nutritionally important fish species. To protect associated ecosystems including mangrove and seagrass, these 
ecosystems should be included in the design of coral reefs MPAs to form a coherent ecological unit (Keller et al., 2009). Mangrove ecosystems associated with coral reefs may help reduce the impact of climate change and OA on coral reefs. For instance, mangroves reduce nutrients suspended in the water column and export dissolve inorganic carbon that buffer the effect of OA on coral reefs locally (Andersson, 2015 ; Sippo et al., 2016).

Networks of MPAs are an important strategy, and should be combined with other management efforts to be effective at reducing $\mathrm{CO}_{2}$ threats on coral reefs by promoting recovery after disturbances as well as allowing for coral migration towards less exposed areas (Keller et al., 2009). The capacity of countries to effectively design, implement, monitor and enforce these types of policies varies across the globe (Mora et al., 2009). There are challenges to implement management measures. MPAs are costly to maintain and may encounter resistance from local populations over conflicts of use. Similarly, fishing restrictions may be harmful for local communities who depend on fishing for subsistence. In order to protect mangroves and other associated ecosystems, it may be desirable to link terrestrial and marine protected areas (Burke et al., 2011). To protect marine and land areas Integrated Coastal Zone Management (ICZM) can be used in coordination with marine protected areas (Rau et al., 2012). Integration of MPAs with coastal zone management is important to coordinate action on reducing both land and marine-based local anthropogenic threats to the resilience of coral reefs.

\subsection{Protecting ecological refugia}

Climate change and ocean acidification will be a major driver of reef degradation in the future (Cinner et al., 2016; Pendleton et al., 2016b). Some areas will be less affected by these effects and can be considered "ecological refugia" that may be sources for coral reefs to thrive again when climate change has been addressed (Chollett and Mumby, 2013). A preliminary requirement for this design feature is to identify ecological connections between habitats, and then protecting them to ensure recruitment in the future (Keller et al., 2009). However, these refugia may ultimately be inadequate to sustain healthy reef ecosystems (Hoegh-Guldberg, 2014). It is therefore argued that places where reefs are less vulnerable to climate change should be protected (Anthony et al., 2015; Mcleod et al., 2013). Refugia are found where thermal stress and where ocean acidification are projected to be lower (Magris et al., 2015; Mumby and Steneck, 2008; Pendleton et al., 2016a). Modelling approaches have been used to attempt to forecast suitability of refugia for coral reefs under higher SST (Chollett and Mumby, 2013; Holstein et al., 2016). Refugia can also be found where corals are more resistant and resilient to thermal stress and ocean acidification (Knudby et al., 2013). Corals in these sites already experience large variations in temperature or acidity conditions, or have the genetic diversity to adapt to future conditions (Billé et al., 2013; Green et al., 2014; Keller et al., 2009). Finally, refugia could be places where other stress are at low levels, for instance places with low cyclone activity (Mcleod et al., 2013), or where local human impacts can be managed well (Harris et al., 2017). 


\begin{tabular}{|c|c|}
\hline Protect & \\
\hline \multirow{16}{*}{$\begin{array}{l}\text { Reduce local stressors to } \\
\text { improve resilience }\end{array}$} & reduce fishing pressure \\
\hline & reduce fishing of herbivores \\
\hline & manage pressures from recreational use \\
\hline & stop destructive fishing practices \\
\hline & protect food provision for organisms \\
\hline & close fisheries \\
\hline & restrict or modify fishing gear used \\
\hline & restrict species fished \\
\hline & restrict access to fisheries \\
\hline & control Crown-of-Thorns Starfish (CoTS) at local scales \\
\hline & protect CoTS predators \\
\hline & tactical CoTS control \\
\hline & monitor and control coral diseases \\
\hline & manage invasive species such as lionfish \\
\hline & regulate trade in reef products internationally \\
\hline & don't obtain construction materials from mining CR \\
\hline \multirow[t]{12}{*}{ Protection of ecosystems } & establish Marine Protected Areas (MPAs) \\
\hline & $\begin{array}{l}\text { enhance reef fish biomass and diversity across depth zones through no-take } \\
\text { marine reserves }\end{array}$ \\
\hline & replicate habitat types in multiple areas to spread risks \\
\hline & Include whole ecological units (e.g., offshore reefs) in marine reserves \\
\hline & $\begin{array}{l}\text { ensure that the full breadth of habitat types is protected (e.g., fringing reef, } \\
\text { fore reef, back reef, patch reef) }\end{array}$ \\
\hline & $\begin{array}{l}\text { identify and protect ecologically significant areas such as nursery grounds, } \\
\text { spawning grounds, and areas of high species diversity }\end{array}$ \\
\hline & protect mesophotic reefs \\
\hline & maximize connectivity within networks of source and sink reefs \\
\hline & $\begin{array}{l}\text { develop networks of marine reserves that protect diverse habitats and } \\
\text { maintain connectivity among reefs }\end{array}$ \\
\hline & $\begin{array}{l}\text { Include/link MPAs with other ecosystems such as seagrass beds and } \\
\text { mangroves }\end{array}$ \\
\hline & link terrestrial and coastal MPAs \\
\hline & $\begin{array}{l}\text { integrate MPAs with coastal zone management to control both marine- and } \\
\text { land-based threats }\end{array}$ \\
\hline \multirow[t]{3}{*}{$\begin{array}{l}\text { Protecting ecological } \\
\text { refugia }\end{array}$} & $\begin{array}{l}\text { identify the sites with high or low resilience that are currently outside } \\
\text { established no-take MPAs }\end{array}$ \\
\hline & $\begin{array}{l}\text { identify and protect areas that appear to be resistant to climate change } \\
\text { effects or to recover from climate-induced disturbances }\end{array}$ \\
\hline & prioritize areas where local threats can be effectively managed \\
\hline
\end{tabular}




\begin{tabular}{|l|l|}
\hline & $\begin{array}{l}\text { prioritize new MPAs based on their historical and projected thermal stress } \\
\text { profile }\end{array}$ \\
\hline & protect locally adapted species \\
\hline & protect of reefs with low exposure from storms \\
\hline & $\begin{array}{l}\text { protect natural refugia (reefs less exposed, less sensitive, and with more } \\
\text { adaptive capacity) }\end{array}$ \\
\hline $\begin{array}{l}\text { protect important ecosystem components to combat locally intensified } \\
\text { acidification }\end{array}$ \\
\hline
\end{tabular}

\section{Repair}

\subsection{Restoring degraded ecosystems}

Coral reefs restoration has been promoted to re-build coral cover in degraded areas. Restoration of coral reefs can take several forms (dela Cruz et al., 2015). Some techniques often called reef gardening involve the cultivation of coral fragments in nurseries and their transplantation in the environment (Rinkevich, 2014). Restoring coral reefs ecosystems may involve physically removing algae, to attract herbivorous fish that are important for the good health of the ecosystem (Adam et al., 2015). Restoration of reefs is essential to break feedbacks that currently keep reefs in degraded states (Adam et al., 2015). Engineering solutions have been proposed, such as translocating corals that are the most adapted to thermal stress within a basin or across basins, and constructing artificial refugees (Coles and Riegl, 2013). Active restoration of corals and reef habitats can be effective if ecological principles are followed, and coral translocation techniques are emerging to do so (Maynard et al., 2015; Mumby and Anthony, 2015; Rogers et al., 2015). The effectiveness of coral restoration through transplantation will depend on the goal of restoration and the choice of species transplanted (Lirman et al., 2014; Muko and Iwasa, 2011). Inversely, restoring CR without managing for external sources of disturbances such as sedimentation may not be effective (Adam et al., 2015). Restoration provides win-win situations where other ecosystem services are provided by the restoration, including GHG sequestration, coastal protection, and improving the resilience of $\mathrm{CR}$ ecosystems.

One of the main barriers of restoration is its cost (Bayraktarov et al., 2016). Restoring coral reefs using transplantation may be feasible, but the cost-effectiveness of this strategy needs to be assessed (Guest et al., 2014). Nonetheless, the cost of restoration is less expensive in developing countries, and markets for ecosystem services could finance the development of reef restoration (Rinkevich, 2015). A clear limit of coral reefs restoration is that the environment in which reefs are restored is still warming and acidifying, so that the underlying threats are still present. Until global threats are dealt with, reefs restoration may be a waste of resources outside of scientific research.

Associated ecosystems, including mangroves and seagrasses, can also be restored to promote biodiversity and resilience of reef systems. While coral reefs and seagrasses are expensive to restore, mangrove restoration is cheaper (Bayraktarov et al., 2016). These associated ecosystems provide important ecosystem function such as fish nurseries. They may also locally mitigate the effects of 
acidification (Camp et al., 2016). Restoration can be conducted upstream with riparian vegetation and wetlands to reduce local threats such as sedimentation and turbidity to coral reefs (Shelton and Richmond, 2016). These can involve coastal floodplain and land vegetation restoration or large dam removal (Kroon et al., 2014).

\subsection{Assist evolution}

One last resort strategy is human-assisted evolution for coral reefs to be able to cope with the increasing threats of thermal stress and ocean acidification (van Oppen et al., 2015). These methods consist in selectively breeding resistant organisms (Billé et al., 2013; Rau et al., 2012; van Oppen et al., 2015), using genetic engineering and protective culturing (Rau et al., 2012). Assisting evolution can be done through induced acclimatization, modification of microbial symbiont community, and evolution of symbiodinium (van Oppen et al., 2015). Ex situ methods include coral nurseries and creating gene banks and can prevent the permanent loss of genetic diversity and help continuing coral reefs in the future. Exposing corals to future environmental conditions in laboratory settings can improve trans-generational acclimation and adaptation in some corals (Chakravarti et al., 2016).

\subsection{Add alkaline material \& local engineering to mitigate CO2 effects}

Several options exist to buffer the effect of ocean acidification on coral reefs locally. Artificial ocean alkalinization, the addition of chemicals and alkaline materials like lime and seashells to the water have been proposed (Billé et al., 2013; Burke et al., 2011; Gattuso et al., 2015; Rau et al., 2012) and may buy some time before ocean acidification impacts coral reefs (Feng (冯玉铭) et al., 2016). Alternatively, waste carbon dioxide can be converted to ocean alkalinity (Rau et al., 2012). Novel engineering techniques to locally increase $\mathrm{pH}$ to delay the negative impacts of ocean acidification are starting to emerge, such as bubble stripping (Koweek et al., 2016) or installing seaweed farms in close proximity to coral reefs to remove carbon from the ocean (Mongin et al., 2016). Engineering solutions proposed to buffer the increase in ocean temperature include artificial shading and artificial upwelling to cool the sea temperature around corals (Rau et al., 2012), and low-voltage direct current to improve coral resistance to environmental change (Rau et al., 2012).

\begin{tabular}{|l|l|}
\hline Repair & \\
\hline Local engineering & install low-voltage direct current \\
\hline & disseminate shell material \\
\hline & reduce acidity with chemicals \\
\hline & add alkaline material, lime and base minerals to increase local pH \\
\hline & convert waste carbon dioxide to ocean alkalinity \\
\hline & $\begin{array}{l}\text { restore ecosystems (seaweed, seagrass beds and mangroves) to buffer local } \\
\text { acidification }\end{array}$ \\
\hline & introduce $\mathrm{CO}_{2}$ bubble stripping \\
\hline & use artificial shading \\
\hline
\end{tabular}




\begin{tabular}{|l|l|}
\hline & use artificial upwelling \\
\hline Assist evolution & selectively breed lines of resistant organisms \\
\hline & actively "thoughen" species \\
\hline & use genetic manipulations techniques \\
\hline & use protective culturing techniques \\
\hline & create gene banks \\
\hline & use induce acclimatization techniques \\
\hline & modify the microbial symbiont community \\
\hline & encourage evolution of symbiodinium \\
\hline Restore degraded & other ex situ methods of preventing permanent loss of genetic diversity \\
\hline ecosystems & restore coral and reef habitat \\
\hline & $\begin{array}{l}\text { restore associated ecosystems: estuaries, oyster reefs, seaweed, seagrass beds } \\
\text { and mangroves }\end{array}$ \\
\hline & translocate coral \\
\hline & construct artificial refuges \\
\hline & increase vegetation cover \\
\hline & remove large dam \\
\hline & restore coastal floodplains \\
\hline & restore land vegetation \\
\hline & restore wetlands \\
\hline & \\
\hline &
\end{tabular}

\section{Adapt}

\subsection{Adapt to the loss of coastal protection}

The destruction of coral reefs because of climate change, OA, and local stressors will hamper the role of natural barrier that coral reefs have, thus increasing erosion and the impact of extreme events on the coastlines (Ferrario et al., 2014; Sheppard et al., 2005). Combining with the other effects of climate change, sea-level rise and increasing extreme weather events (Cinner et al., 2016), coastal populations will have to adapt to the loss of coastal protection provided by reefs. First, soft options exist, such as local planning for storm preparedness and recovery (Anthony et al., 2015). Forecasting and response capabilities to coastal disasters can be improved with prevention and management systems (Cai et al., 2015). Hard solutions, like coastal infrastructure for flood protection, can compensate the loss of natural coastal protection (Cai et al., 2015). In case of situations where conditions do not allow for coastline protection, compensatory measures can be taken such as investments in social protection and alternative livelihoods (Anthony et al., 2015).

\subsection{Adapt to the loss of livelihood in fishing and tourism}

Fishing and tourism are two of the most important economic activities linked to coral reefs worldwide. Human populations who dependent on reef fish for their livelihood will have to adapt (Teh et al., 2013). 
Altered human behavior in fishing areas can improve fish biomass and diversity (Graham et al., 2013). Changing practices can involve changing fishing gear towards the ones less impacted by coral bleaching such as hand lines (Cinner et al., 2013). Fishing effort can shift from traditional stocks towards underexploited ones or towards aquaculture (MacNeil et al., 2010). Technical and financial strategies to cope with the impacts of GEC on reef fish exist, including capital investment in fisheries (MacNeil et al., 2010), expansion of fair trade and green markets (Hughes et al., 2012), or decreasing exports of reef fishes (Mumby and Steneck, 2008). The seafood supply chain can adapt on several fronts including fuel efficiency, industry structure and regulations, or breeding programs (Weatherdon et al., 2016). In case of severe impacts, programs to deal with reef-fisheries collapse can be implemented (MacNeil et al., 2010). Supporting alternative livelihood is commonly referenced as an adaptation strategy in the literature (Anthony et al., 2015; Cinner et al., 2013; MacNeil et al., 2010; Weatherdon et al., 2016), even though the effect of fisheries and aquaculture on food security is unclear (Béné et al., 2016). Alternative sources of protein from agriculture and aquaculture can be found (Hughes et al., 2012). Infrastructure development in rural areas can be used to relocate communities that will be impacted by the loss reef fishes (Cinner et al., 2013). The tourism industry will also be impacted by the loss of coral reefs, and will need to adapt (Anthony et al., 2015), for instance through sustainable tourism practices (Burke et al., 2011).

\subsection{Relocate activities, and migrate}

The loss of ecosystem services will also weaken the economic network of coastal communities. Several actions can aim at improving the socio-economic situation of these communities. Because the loss of coral reefs will not be uniform across space and time, it may be feasible to relocate activities and species in areas less affected, for example where ocean acidification will be lower (Billé et al., 2013). International companies in the fishing and tourism sector could also relocate their activities (Weatherdon et al., 2016). Where impacts will be very high and people are very dependent on coral reefs, migration could be the only option in the future. In addition, some people may be displaced or will have to change activity because of the establishment of protected areas, and these people will need assistance to transition (Mumby and Steneck, 2008).

\subsection{Ecosystem-based adaptation}

While coral reefs ecosystems are under threat from climate change, in some cases reefs and associated ecosystems can be maintained to help humans adapt to the direct negative effects of climate change. These strategies are termed ecosystem-based adaptation or nature-based solutions to climate change (Jones et al., 2012). Protecting and restoring coastal habitats and managing coastal realignments are options to proactively plan for future conditions (Weatherdon et al., 2016). Coral reefs and mangroves have been shown to dissipate wave energy and thus protect coastlines (Villanoy et al., 2012). Planning mechanisms such as zoning can anticipate climate-related impacts such as sea-level rise to minimize them. In addition, the cost of coral reefs restoration may be less expensive than the cost of building coastal protection infrastructure so that it may be feasible and cost-effective to use coral restoration for ecosystem-based adaptation (Ferrario et al., 2014; Narayan et al., 2016). 


\begin{tabular}{|c|c|}
\hline Adapt & \\
\hline \multirow[t]{6}{*}{$\begin{array}{l}\text { Adapt to the loss of coastal } \\
\text { protection }\end{array}$} & $\begin{array}{l}\text { promote marine climate-disaster forecasting and response } \\
\text { capability }\end{array}$ \\
\hline & plan for preparedness and recovery locally \\
\hline & $\begin{array}{l}\text { install climate-related coastal disaster prevention and management } \\
\text { systems }\end{array}$ \\
\hline & build coastal infrastructure for flood protection and drainage \\
\hline & $\begin{array}{l}\text { invest in alternative livelihoods and social protection for those } \\
\text { displaced because of habitat protection }\end{array}$ \\
\hline & invest in insurance schemes \\
\hline \multirow[t]{25}{*}{$\begin{array}{l}\text { Adapt to the loss of livelihood } \\
\text { from tourism and fisheries }\end{array}$} & $\begin{array}{l}\text { work with fishers and tourism operators to help build resilience in } \\
\text { their industries }\end{array}$ \\
\hline & $\begin{array}{l}\text { adapt revenue-generating activities such as fisheries and } \\
\text { aquaculture to OA }\end{array}$ \\
\hline & $\begin{array}{l}\text { promote the use of gears less likely to be negatively impacted by } \\
\text { coral bleaching (e.g. hand lines) }\end{array}$ \\
\hline & $\begin{array}{l}\text { shift target species from traditional stocks to new or underutilized } \\
\text { ones, and to aquaculture }\end{array}$ \\
\hline & capital investments in fisheries \\
\hline & altered human behavior in fishing areas \\
\hline & boost fair trade and green markets \\
\hline & use fish-aggregation devices \\
\hline & fishing training \\
\hline & gear provision \\
\hline & transitioning traditional to novel fisheries \\
\hline & decrease international export of reef fishes \\
\hline & $\begin{array}{l}\text { adapt seafood supply chain (fuel efficiency, breeding programs, } \\
\text { altered industry structure, simplified regulations) }\end{array}$ \\
\hline & increase flexibility through alternative fisheries \\
\hline & simplify regulations \\
\hline & develop sustainable fisheries management plans \\
\hline & improve income inequality and trade deficits to improve flexibility \\
\hline & increase sources of protein and nutrient dense food \\
\hline & increase availability and accessibility of alternative protein sources \\
\hline & $\begin{array}{l}\text { increase alternate protein sources through agriculture and } \\
\text { aquaculture }\end{array}$ \\
\hline & Increase incentives for nondestructive harvest of resource \\
\hline & encourage and improve aquaculture \\
\hline & diversify livelihoods in response to reduced production \\
\hline & establish programs to deal with reef-fisheries collapse \\
\hline & implement sustainable tourism \\
\hline
\end{tabular}




\begin{tabular}{|c|c|}
\hline & Tourism outreach and stewardship \\
\hline & support alternative livelihoods transitioning \\
\hline & develop supplemental livelihood activities \\
\hline & compensatory measures \\
\hline & social protection \\
\hline & migrate activities where $\mathrm{OA}$ is lower \\
\hline & co-management \\
\hline & Microcredit schemes \\
\hline & support for community savings \\
\hline & Eradication of corruption \\
\hline & Support for economic growth \\
\hline & Poverty alleviation plans and pro-poor growth policies \\
\hline & boost financial, natural, and physical assets \\
\hline & improve labor policies and practices to decrease inequalities \\
\hline & infrastructure development in rural areas \\
\hline & increase social mechanisms for sustainability \\
\hline & $\begin{array}{l}\text { use climate funding to reduce vulnerability of CR-dependent } \\
\text { communities }\end{array}$ \\
\hline \multirow[t]{10}{*}{ Ecosystem based adaptation } & use coastal ecosystems to protect asset \\
\hline & $\begin{array}{l}\text { Managing realignment of coastal ecosystems as they migrate } \\
\text { landwards or poleward }\end{array}$ \\
\hline & $\begin{array}{l}\text { hybrid engineering structures can provide an integrated way of } \\
\text { conserving ecosystems and ecosystem services }\end{array}$ \\
\hline & maintaining species biodiversity \\
\hline & restoring and maintaining coastal habitats \\
\hline & maximizing ecosystem services in degraded reefs \\
\hline & provision of artificial complexity \\
\hline & coral restoration \\
\hline & habitat migration \\
\hline & integrated coastal management \\
\hline \multirow[t]{6}{*}{ Migration and displacement } & migrate activities where OA and CC impacts are lower \\
\hline & displacement linked to livelihood transitioning \\
\hline & migrate activities \\
\hline & relocate international investments \\
\hline & relocate species \\
\hline & conserve reefs ex-situ \\
\hline
\end{tabular}




\section{Indirect strategies}

\subsection{Research and Monitoring}

The main objectives of the articles reviewed here are to understand the impacts of climate change, ocean acidification, and/or local stressors on coral reefs ecosystems, how their vulnerability and resilience will be influenced by such changes and how they will be affected in the future. In some cases, studies attempt to understand how these will impact society (e.g. Johnson and Welch, 2016). Climate change models can be important tools to provide information to decision-makers and managers. Several scientific articles discuss improving forecasting abilities to better manage for future conditions and to include more potential impacts such as diseases (Caldwell et al., 2016; Harvell et al., 2004). Future projections can help management and design of future MPAs to protect potential refugia (Chollett et al., 2014; Magris et al., 2015). Monitoring is an essential management tool for ecosystems like coral reefs that are prone to phase shifts (Selkoe et al., 2015) and needs to integrate various tools such as remote sensing (Hedley et al., 2016), as well as field data on ecosystem health and resilience and socio-economic impacts (Zeller et al., 2016). Monitoring conditions can be used in adaptive management of coral reefs to improve their resilience (Ladd and Collado-Vides, 2013). Better collection of baseline ocean conditions (Strong et al., 2014), ecological conditions, and socio-economic routine collection data (Pendleton et al., 2016a, 2016b) is needed for future research and management success. In addition to data collection for monitoring and management, long term studies are needed to understand the evolution of ecological and social systems over time, and the effectiveness of management strategies over time (Morrison, 2017).

\subsection{Capacity building}

Managers, decision-makers, and stakeholders that have a footprint on coral reefs will not act if they are not aware of the problem. Raising awareness to a wide variety of stakeholders is a first step towards action. Communication can be done through scientific engagement with the public (Schuldt et al., 2016). Community engagement on climate change between researchers and local communities is building their capacity to respond to climate hazards (Leon et al., 2015). Direct engagement of scientists with managers, decision-makers, and other stakeholders such as fishing, tourism, and agriculture communities can improve their capacity to act and help change practices. For instance, there is a lack of understanding of adaptive management and adaptation by governments and MPA managers (Hopkins et al., 2016). Scientists can work with local communities that depend on fishing and tourism to develop adaptation and livelihood transitioning strategies (Anthony et al., 2015).

Governance regimes and institutions are very important to ensure the implementation and success of management strategies (Barnett et al., 2015; Cvitanovic et al., 2014). Collaboration between countries across different scales of governance can help build capacity where it is lacking (Kim, 2012). International agreements and treaties such as the Paris Agreement on climate change are foundations to ensure the implementation of management strategies to deal with the impacts of GEC on coral reefs and their ecosystem services. International scientific cooperation can also improve understanding and management of coral reefs to respond to future threats, especially ocean acidification (Strong et al., 2014). Studies are conducted to better understand the ability of governance regimes, policies and 
institutions that focus on coral reefs ecosystems to respond to the threats of climate change (Dale et al., 2013; Zeppel, 2012) and people's perceptions of the effectiveness of these governance regimes (Huang and You, 2013). While it seems that coordination and integration of governing bodies across scales and across sectors is recommended to respond to the threats of climate change on coral reefs SES, few studies have focused on these aspects so far (Lebel, 2012).

\begin{tabular}{|c|c|}
\hline Indirect & \\
\hline \multirow{23}{*}{$\begin{array}{l}\text { Research and } \\
\text { monitoring }\end{array}$} & develop climate models \\
\hline & project changes in seawater chemistry \\
\hline & observe, study, and assess climate change and ocean acidification \\
\hline & $\begin{array}{l}\text { coordinate domestic research and communication efforts with international } \\
\text { programs to amplify attention to } \mathrm{OA}\end{array}$ \\
\hline & identify synergistic effects of multiple stressors \\
\hline & extend research on impacts, dependence, resilience, and adaptation \\
\hline & $\begin{array}{l}\text { national and international funding in research and human capacity to understand } \\
\text { the ecology }\end{array}$ \\
\hline & funding in research and human capacity \\
\hline & public participation in research \\
\hline & conduct economic valuation \\
\hline & $\begin{array}{l}\text { continue developing a coordinated regional network of monitoring stations to } \\
\text { map the vulnerability of coastal areas to OA }\end{array}$ \\
\hline & $\begin{array}{l}\text { collect data and create network systems for sharing for the management of } \\
\text { environmental stressors }\end{array}$ \\
\hline & monitoring state of ecosystem using indicators (and thresholds) \\
\hline & establish ocean chemistry baseline \\
\hline & standardize global monitoring on $\mathrm{OA}$ \\
\hline & establish ecological baselines \\
\hline & determine easy-to-measure biological indicators as proxies for ecosystem health \\
\hline & determine species, habitat, and community sensitivity \\
\hline & $\begin{array}{l}\text { monitoring socio-economic state using indicators (and thresholds of poverty } \\
\text { traps) }\end{array}$ \\
\hline & $\begin{array}{l}\text { measure and monitor changes the ocean's physical, chemical, and biological } \\
\text { response }\end{array}$ \\
\hline & monitoring near-shore systems \\
\hline & extend monitoring to near-shore systems relevant to management jurisdictions \\
\hline & monitor management of herbivore fishing \\
\hline Capacity building & $\begin{array}{l}\text { influence national emissions policies through education and awareness raising } \\
\text { around climate change, land use and run-off }\end{array}$ \\
\hline
\end{tabular}




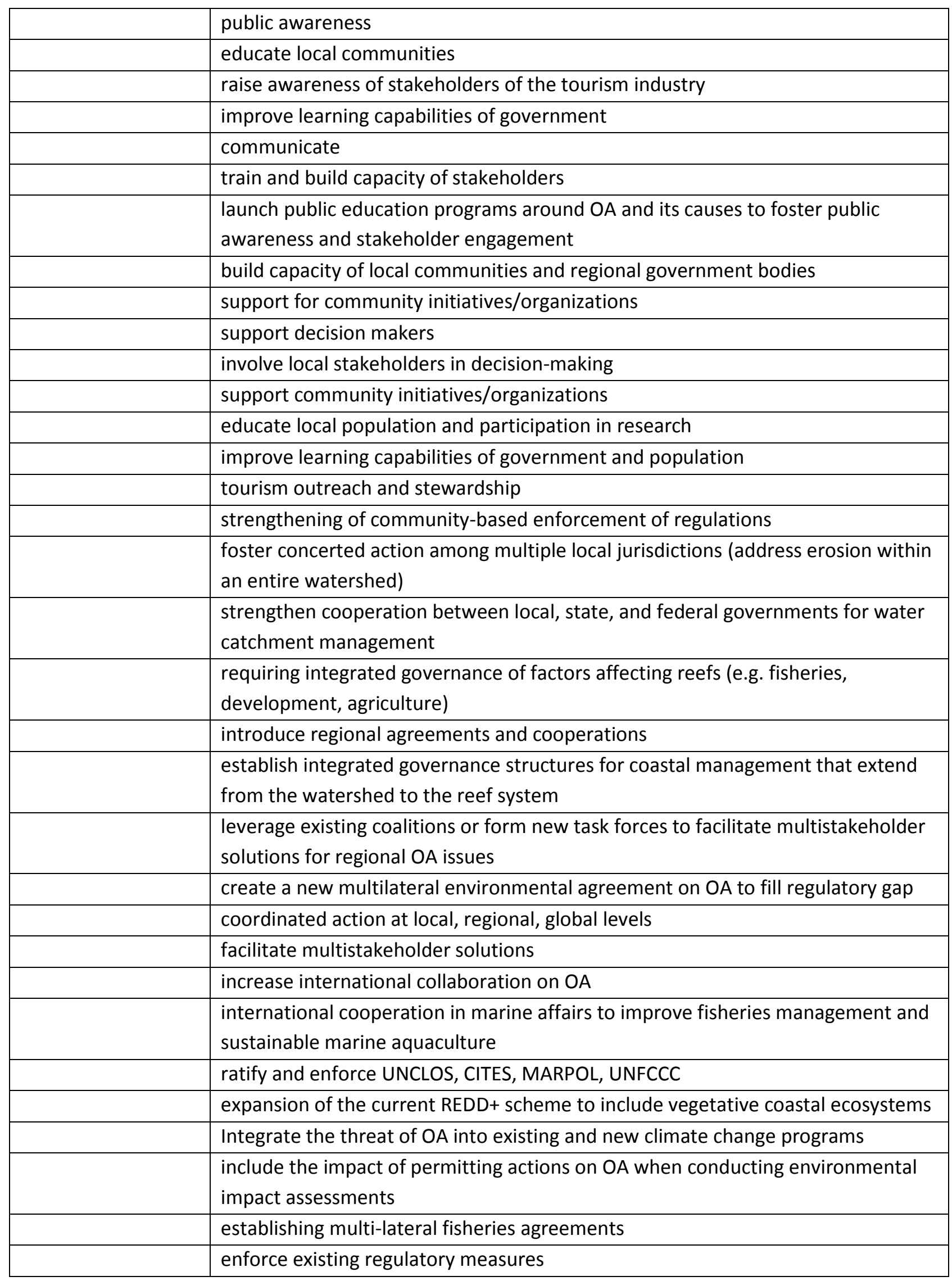


climate funding to reduce vulnerability

change governance systems towards co-management

\section{References}

Adam, T.C., Burkepile, D.E., Ruttenberg, B.I., Paddack, M.J., 2015. Herbivory and the resilience of Caribbean coral reefs: knowledge gaps and implications for management. Mar. Ecol. Prog. Ser. 520, 1-20. doi:10.3354/meps11170

Andersson, A.J., 2015. A fundamental paradigm for coral reef carbonate sediment dissolution . Front. Mar. Sci. doi:10.3389/fmars.2015.00052

Anthony, K.R.N., Marshall, P.A., Abdulla, A., Beeden, R., Bergh, C., Black, R., Eakin, C.M., Game, E.T., Gooch, M., Graham, N.A.J., Green, A., Heron, S.F., van Hooidonk, R., Knowland, C., Mangubhai, S., Marshall, N., Maynard, J.A., McGinnity, P., McLeod, E., Mumby, P.J., Nyström, M., Obura, D., Oliver, J., Possingham, H.P., Pressey, R.L., Rowlands, G.P., Tamelander, J., Wachenfeld, D., Wear, S., 2015. Operationalizing resilience for adaptive coral reef management under global environmental change. Glob. Chang. Biol. 21, 48-61. doi:10.1111/gcb.12700

Ateweberhan, M., Feary, D.A., Keshavmurthy, S., Chen, A., Schleyer, M.H., Sheppard, C.R.C., 2013. Climate change impacts on coral reefs: synergies with local effects, possibilities for acclimation, and management implications. Mar. Pollut. Bull. 74, 526-539. doi:10.1016/j.marpolbul.2013.06.011

Barnett, J., Evans, L.S., Gross, C., Kiem, A.S., Kingsford, R.T., Palutikof, J.P., Pickering, C., 2015. From barriers to limits to climate change adaptation: path dependency and the speed of change. Ecol. Soc. 20, art5. doi:10.5751/ES-07698-200305

Bayraktarov, E., Saunders, M.I., Abdullah, S., Mills, M., Beher, J., Possingham, H.P., Mumby, P.J., Lovelock, C.E., 2016. The cost and feasibility of marine coastal restoration. Ecol. Appl. 26, 10551074. doi:10.5061/dryad.rc0jn

Béné, C., Arthur, R., Norbury, H., Allison, E.H., Beveridge, M., Bush, S., Campling, L., Leschen, W., Little, D., Squires, D., Thilsted, S.H., Troell, M., Williams, M., 2016. Contribution of Fisheries and Aquaculture to Food Security and Poverty Reduction: Assessing the Current Evidence. World Dev. 79, 177-196. doi:10.1016/j.worlddev.2015.11.007

Billé, R., Kelly, R., Biastoch, A., Harrould-Kolieb, E., Herr, D., Joos, F., Kroeker, K., Laffoley, D., Oschlies, A., Gattuso, J.-P., 2013. Taking action against ocean acidification: a review of management and policy options. Environ. Manage. 52, 761-779. doi:10.1007/s00267-013-0132-7

Bozec, Y.-M., O'Farrell, S., Bruggemann, J.H., Luckhurst, B.E., Mumby, P.J., 2016. Tradeoffs between fisheries harvest and the resilience of coral reefs. Proc. Natl. Acad. Sci. 113, 201601529.

doi:10.1073/pnas.1601529113 
Brodie, J., Pearson, R.G., 2016. Ecosystem health of the Great Barrier Reef: time for effective management action based on evidence. Estuar. Coast. Shelf Sci. TBA, 438-451. doi:10.1016/j.ecss.2016.05.008

Bruno, J.F., Valdivia, A., 2016. Coral reef degradation is not correlated with local human population density. Sci. Rep. 6, 29778. doi:10.1038/srep29778

Burke, L., Reytar, K., Spalding, M., Perry, A., 2011. Reefs at risk Revisited, World Resources Institute. Washington, D.C. doi:10.1016/0022-0981(79)90136-9

Cai, R., Tan, H., Qi, Q., 2015. Impacts of and adaptation to inter-decadal marine climate change in coastal China seas. Int. J. Climatol. doi:10.1002/joc.4591

Caldwell, J., Heron, S., Eakin, C., Donahue, M., 2016. Satellite SST-Based Coral Disease Outbreak Predictions for the Hawaiian Archipelago. Remote Sens. 8, 93. doi:10.3390/rs8020093

Camp, E.F., Suggett, D.J., Gendron, G., Jompa, J., Manfrino, C., Smith, D.J., 2016. Mangrove and seagrass beds provide different biogeochemical services for corals threatened by climate change. Front. Mar. Sci. 3, 52. doi:10.3389/fmars.2016.00052

Chakravarti, L.J., Jarrold, M.D., Gibbin, E.M., Christen, F., Massamba-N'Siala, G., Blier, P.U., Calosi, P., 2016. Can trans-generational experiments be used to enhance species resilience to ocean warming and acidification. Evol. Appl. 9, 1133-1146. doi:10.1111/eva.12391

Chollett, I., Enr?quez, S., Mumby, P.J., 2014. Redefining Thermal Regimes to Design Reserves for Coral Reefs in the Face of Climate Change. PLoS One 9, e110634. doi:10.1371/journal.pone.0110634

Chollett, I., Mumby, P.J., 2013. Reefs of last resort: Locating and assessing thermal refugia in the wider Caribbean. Biol. Conserv. 167, 179-186. doi:10.1016/j.biocon.2013.08.010

Cinner, J.E., Huchery, C., Darling, E.S., Humphries, A.T., Graham, N.A.J., Hicks, C.C., Marshall, N., McClanahan, T.R., 2013. Evaluating social and ecological vulnerability of coral reef fisheries to climate change. PLoS One 8, e74321. doi:10.1371/journal.pone.0074321

Cinner, J.E., Pratchett, M.S., Graham, N.A.J., Messmer, V., Fuentes, M.M.P.B., Ainsworth, T., Ban, N., Bay, L.K., Blythe, J., Dissard, D., Dunn, S., Evans, L., Fabinyi, M., Fidelman, P., Figueiredo, J., Frisch, A.J., Fulton, C.J., Hicks, C.C., Lukoschek, V., Mallela, J., Moya, A., Penin, L., Rummer, J.L., Walker, S., Williamson, D.H., 2016. A framework for understanding climate change impacts on coral reef social-ecological systems. Reg. Environ. Chang. 16, 1133-1146. doi:10.1007/s10113-015-0832-z

Coles, S.L., Riegl, B.M., 2013. Thermal tolerances of reef corals in the Gulf: A review of the potential for increasing coral survival and adaptation to climate change through assisted translocation. Mar. Pollut. Bull. 72, 323-332. doi:10.1016/j.marpolbul.2012.09.006

Côté, S., Green, I., 2012. Potential effects of climate change on a marine invasion: The importance of current context. Curr. Zool. Vol. 58 Issue 1 (pp 1-8).

Crabbe, M.J.C., 2009. Modelling effects of geoengineering options in response to climate change and global warming: implications for coral reefs. Comput. Biol. Chem. 33, 415-420. doi:10.1016/j.compbiolchem.2009.09.004

Cvitanovic, C., Marshall, N.A., Wilson, S.K., Dobbs, K., Hobday, A.J., 2014. Perceptions of Australian 
marine protected area managers regarding the role, importance, and achievability of adaptation for managing the risks of climate change. Ecol. Soc. 19, art33. doi:10.5751/ES-07019-190433

Dale, A., Vella, K., Pressey, R.L., Brodie, J., Yorkston, H., Potts, R., 2013. A method for risk analysis across governance systems: a Great Barrier Reef case study. Environ. Res. Lett. 8, 15037. doi:10.1088/1748-9326/8/1/015037

Das, S., Vincent, J.R., 2009. Mangroves protected villages and reduced death toll during Indian super cyclone. Proc. Natl. Acad. Sci. 106, 7357-7360. doi:10.1073/pnas.0810440106

dela Cruz, D.W., Rinkevich, B., Gomez, E.D., Yap, H.T., 2015. Assessing an abridged nursery phase for slow growing corals used in coral restoration. Ecol. Eng. 84, 408-415. doi:10.1016/j.ecoleng.2015.09.042

Feng (冯玉铭), E.Y., Keller, D.P., Koeve, W., Oschlies, A., 2016. Could artificial ocean alkalinization protect tropical coral ecosystems from ocean acidification? Environ. Res. Lett. 11, 74008. doi:10.1088/1748-9326/11/7/074008

Ferrario, F., Beck, M.W., Storlazzi, C.D., Micheli, F., Shepard, C.C., Airoldi, L., 2014. The effectiveness of coral reefs for coastal hazard risk reduction and adaptation. Nat. Commun. 5, 3794. doi:10.1038/ncomms4794

Gattuso, J.-P., Magnan, A., Billé, R., Cheung, W.W.L., Howes, E.L., Joos, F., Allemand, D., Bopp, L., Cooley, S.R., Eakin, C.M., Hoegh-Guldberg, O., Kelly, R.P., Portner, H.-O., Rogers, a. D., Baxter, J.M., Laffoley, D., Osborn, D., Rankovic, A., Rochette, J., Sumaila, U.R., Treyer, S., Turley, C., 2015. Contrasting futures for ocean and society from different anthropogenic $\mathrm{CO} 2$ emissions scenarios. Science (80-. ). 349. doi:http://dx.doi.org/10.1126/science.aac4722

Graham, N.A.J., Bellwood, D.R., Cinner, J.E., Hughes, T.P., Norström, A. V., Nyström, M., 2013. Managing resilience to reverse phase shifts in coral reefs. Front. Ecol. Environ. 11, 541-548.

doi:10.1890/120305

Green, A.L., Fernandes, L., Almany, G., Abesamis, R., McLeod, E., Aliño, P.M., White, A.T., Salm, R., Tanzer, J., Pressey, R.L., 2014. Designing Marine Reserves for Fisheries Management, Biodiversity Conservation, and Climate Change Adaptation. Coast. Manag. 42, 143-159. doi:10.1080/08920753.2014.877763

Grieve, B., Curchitser, E., Rykaczewski, R., 2016. Range expansion of the invasive lionfish in the Northwest Atlantic with climate change. Mar. Ecol. Prog. Ser. 546, 225-237. doi:10.3354/meps11638

Guest, J.R., Baria, M. V., Gomez, E.D., Heyward, A.J., Edwards, A.J., 2014. Closing the circle: Is it feasible to rehabilitate reefs with sexually propagated corals? Coral Reefs 33, 45-55. doi:10.1007/s00338013-1114-1

Harris, J.L., Estradivari, E., Fox, H.E., McCarthy, O.S., Ahmadia, G.N., 2017. Planning for the future: Incorporating global and local data to prioritize coral reef conservation. Aquat. Conserv. Mar. Freshw. Ecosyst. 27, 65-77. doi:10.1002/aqc.2810

Harrould-Kolieb, E.R., Herr, D., 2012. Ocean acidification and climate change: synergies and challenges of addressing both under the UNFCCC. Clim. Policy 12, 378-389. doi:10.1080/14693062.2012.620788 
Harvell, D., Aronson, R., Baron, N., Connell, J., Dobson, A., Ellner, S., Gerber, L., Kim, K., Kuris, A., McCallum, H., Lafferty, K., McKay, B., Porter, J., Pascual, M., Smith, G., Sutherland, K., Ward, J., 2004. The rising tide of ocean diseases: unsolved problems and research priorities. Front. Ecol. Environ. 2, 375-382. doi:10.2307/3868363

Hedley, J., Roelfsema, C., Chollett, I., Harborne, A., Heron, S., Weeks, S., Skirving, W., Strong, A., Eakin, C., Christensen, T., Ticzon, V., Bejarano, S., Mumby, P., 2016. Remote Sensing of Coral Reefs for Monitoring and Management: A Review. Remote Sens. 8, 118. doi:10.3390/rs8020118

Hoegh-Guldberg, O., 2014. Coral reefs in the Anthropocene: persistence or the end of the line? Geol. Soc. London, Spec. Publ. 395, 167-183. doi:10.1144/SP395.17

Holstein, D.M., Paris, C.B., Vaz, A.C., Smith, T.B., 2016. Modeling vertical coral connectivity and mesophotic refugia. Coral Reefs 35, 23-37. doi:10.1007/s00338-015-1339-2

Hopkins, C.R., Bailey, D.M., Potts, T., 2016. Perceptions of practitioners: Managing marine protected areas for climate change resilience. Ocean Coast. Manag. 128, 18-28. doi:10.1016/j.ocecoaman.2016.04.014

Huang, H.-W., You, M.-H., 2013. Public Perception of Ocean Governance and Marine Resources Management in Taiwan. Coast. Manag. 41, 420-438. doi:10.1080/08920753.2013.822288

Hughes, S., Yau, A., Max, L., Petrovic, N., Davenport, F., Marshall, M., McClanahan, T.R., Allison, E.H., Cinner, J.E., 2012. A framework to assess national level vulnerability from the perspective of food security: The case of coral reef fisheries. Environ. Sci. Policy 23, 95-108. doi:10.1016/j.envsci.2012.07.012

Hughes, T.P., Baird, A., Bellwood, D., 2003. Climate Change, Human Impacts, and the Resilience of Coral Reefs. Science (80-. ). 301, 929-933. doi:10.1126/science.1085046

Hughes, T.P., Kerry, J., Álvarez-Noriega, M., Álvarez-Romero, J., Anderson, K., Baird, A., Babcock, R., Beger, M., Bellwood, D., Berkelmans, R., Bridge, T., Butler, I., Byrne, M., Cantin, N., Comeau, S., Connolly, S., Cumming, G., Dalton, S., Diaz-Pulido, G., Eakin, C.M., Figueira, W., Gilmour, J., Harrison, H., Heron, S., Hoey, A.S., Hobbs, J.-P., Hoogenboom, M., Kennedy, E., Kuo, C.-Y., Lough, J., Lowe, R., Liu, G., Malcolm McCulloch, H.M., McWilliam, M., Pandolfi, J., Pears, R., Pratchett, M., Schoepf, V., Simpson, T., Skirving, W., Sommer, B., Torda, G., Wachenfeld, D., Willis, B., Wilson, S., 2017. Global warming and recurrent mass bleaching of corals. Nature. doi:10.1038/nature21707

Hughes, T.P., Rodrigues, M.J., Bellwood, D.R., Ceccarelli, D., Hoegh-Guldberg, O., McCook, L., Moltschaniwskyj, N., Pratchett, M.S., Steneck, R.S., Willis, B., 2007. Phase shifts, herbivory, and the resilience of coral reefs to climate change. Curr. Biol. 17, 360-365. doi:10.1016/j.cub.2006.12.049

Johnson, J.E., Welch, D.J., 2016. Climate change implications for Torres Strait fisheries: assessing vulnerability to inform adaptation. Clim. Change 135, 611-624. doi:10.1007/s10584-015-1583-z

Jones, H.P., Hole, D.G., Zavaleta, E.S., 2012. Harnessing nature to help people adapt to climate change. Nat. Clim. Chang. 2, 504-509. doi:10.1038/nclimate1463

Keller, B.D., Gleason, D.F., McLeod, E., Woodley, C.M., Airamé, S., Causey, B.D., Friedlander, A.M., Grober-Dunsmore, R., Johnson, J.E., Miller, S.L., Steneck, R.S., 2009. Climate Change, Coral Reef Ecosystems, and Management Options for Marine Protected Areas. Environ. Manage. 44, 1069- 
1088. doi:10.1007/s00267-009-9346-0

Kelly, R.P., Foley, M.M., Fisher, W.S., Feely, R. a, Halpern, B.S., Waldbusser, G.G., Caldwell, M.R., 2011. Mitigating Local Causes of Ocean Acidification with Existing Laws. Science (80-. ). 332, 1036-1037. doi:10.1126/science.1203815

Kim, R.E., 2012. Is a New Multilateral Environmental Agreement on Ocean Acidification Necessary? Rev. Eur. Community Int. Environ. Law 21, 243-258. doi:10.1111/reel.12000.x

Knudby, A., Jupiter, S., Roelfsema, C., Lyons, M., Phinn, S., 2013. Mapping Coral Reef Resilience Indicators Using Field and Remotely Sensed Data. Remote Sens. 5, 1311-1334. doi:10.3390/rs5031311

Koweek, D.A., Mucciarone, D.A., Dunbar, R.B., 2016. Bubble Stripping as a Tool To Reduce High Dissolved CO 2 in Coastal Marine Ecosystems. Environ. Sci. Technol. 50, 3790-3797. doi:10.1021/acs.est.5b04733

Kroon, F.J., Schaffelke, B., Bartley, R., 2014. Informing policy to protect coastal coral reefs: Insight from a global review of reducing agricultural pollution to coastal ecosystems. Mar. Pollut. Bull. 85, 33-41. doi:10.1016/j.marpolbul.2014.06.003

Ladd, M.C., Collado-Vides, L., 2013. Practical applications of monitoring results to improve managing for coral reef resilience: a case study in the Mexican Caribbean. Biodivers. Conserv. 22, 1591-1608. doi:10.1007/s10531-013-0493-5

Lamb, J.B., Wenger, A.S., Devlin, M.J., Ceccarelli, D.M., Williamson, D.H., Willis, B.L., 2016. Reserves as tools for alleviating impacts of marine disease. Philos. Trans. R. Soc. B Biol. Sci. 371, 20150210. doi:10.1098/rstb.2015.0210

Lamb, J.B., Williamson, D.H., Russ, G.R., Willis, B.L., 2015. Protected areas mitigate diseases of reefbuilding corals by reducing damage from fishing. Ecology 96, 2555-2567. doi:10.1890/14-1952.1

Lebel, L., 2012. Governance and coastal boundaries in the tropics. Curr. Opin. Environ. Sustain. 4, 243251. doi:10.1016/j.cosust.2011.12.001

Leon, J.X., Hardcastle, J., James, R., Albert, S., Kereseka, J., Woodroffe, C.D., 2015. Supporting Local and Traditional Knowledge with Science for Adaptation to Climate Change: Lessons Learned from Participatory Three-Dimensional Modeling in BoeBoe, Solomon Islands. Coast. Manag. 43, 424-438. doi:10.1080/08920753.2015.1046808

Lirman, D., Schopmeyer, S., Galvan, V., Drury, C., Baker, A.C., Baums, I.B., 2014. Growth Dynamics of the Threatened Caribbean Staghorn Coral Acropora cervicornis: Influence of Host Genotype, Symbiont Identity, Colony Size, and Environmental Setting. PLoS One 9, e107253. doi:10.1371/journal.pone.0107253

MacNeil, M.A., Graham, N.A.J., Cinner, J.E., Dulvy, N.K., Loring, P.A., Jennings, S., Polunin, N.V.C., Fisk, A.T., McClanahan, T.R., 2010. Transitional states in marine fisheries: adapting to predicted global change. Philos. Trans. R. Soc. B Biol. Sci. 365, 3753-3763. doi:10.1098/rstb.2010.0289

MacNeil, M.A., Graham, N.A.J., Cinner, J.E., Wilson, S.K., Williams, I.D., Maina, J., Newman, S., Friedlander, A.M., Jupiter, S., Polunin, N.V.C., McClanahan, T.R., 2015. Recovery potential of the world's coral reef fishes. Nature 520, 341-344. doi:10.1038/nature14358 
Magdaong, E.T., Fujii, M., Yamano, H., Licuanan, W.Y., Maypa, A., Campos, W.L., Alcala, A.C., White, A.T., Apistar, D., Martinez, R., 2014. Long-term change in coral cover and the effectiveness of marine protected areas in the Philippines: A meta-analysis. Hydrobiologia 733, 5-17. doi:10.1007/s10750013-1720-5

Magris, R.A., Heron, S.F., Pressey, R.L., 2015. Conservation Planning for Coral Reefs Accounting for Climate Warming Disturbances. PLoS One 10, e0140828. doi:10.1371/journal.pone.0140828

Maynard, J.A., McKagan, S., Raymundo, L., Johnson, S., Ahmadia, G.N., Johnston, L., Houk, P., Williams, G.J., Kendall, M., Heron, S.F., van Hooidonk, R., Mcleod, E., Tracey, D., Planes, S., 2015. Assessing relative resilience potential of coral reefs to inform management. Biol. Conserv. 192, 109-119. doi:10.1016/j.biocon.2015.09.001

McClanahan, T.R., Cinner, J.E., Graham, N.A.J., Daw, T.M., Maina, J., Stead, S.M., Wamukota, A., Brown, K., Venus, V., Polunin, N.V.C., 2009. Identifying Reefs of Hope and Hopeful Actions: Contextualizing Environmental, Ecological, and Social Parameters to Respond Effectively to Climate Change. Conserv. Biol. 23, 662-671. doi:10.1111/j.1523-1739.2008.01154.x

Mcleod, E., Anthony, K.R.N., Andersson, A., Beeden, R., Golbuu, Y., Kleypas, J., Kroeker, K., Manzello, D., Salm, R. V, Schuttenberg, H., Smith, J.E., 2013. Preparing to manage coral reefs for ocean acidification: lessons from coral bleaching. Front. Ecol. Environ. 11, 20-27. doi:10.1890/110240

Mongin, M., Baird, M.E., Hadley, S., Lenton, A., 2016. Optimising reef-scale CO 2 removal by seaweed to buffer ocean acidification. Environ. Res. Lett. 11, 34023. doi:10.1088/1748-9326/11/3/034023

Mora, C., Myers, R. a, Coll, M., Libralato, S., Pitcher, T.J., Sumaila, R.U., Zeller, D., Watson, R., Gaston, K.J., Worm, B., 2009. Management effectiveness of the world's marine fisheries. PLoS Biol. 7, e1000131. doi:10.1371/journal.pbio.1000131

Morrison, T.H., 2017. Evolving polycentric governance of the Great Barrier Reef. Proc. Natl. Acad. Sci. 114, E3013-E3021. doi:10.1073/pnas.1620830114

Muko, S., Iwasa, Y., 2011. Long-term effect of coral transplantation: Restoration goals and the choice of species. J. Theor. Biol. 280, 127-138. doi:10.1016/j.jtbi.2011.04.012

Mumby, P.J., Anthony, K.R.N., 2015. Resilience metrics to inform ecosystem management under global change with application to coral reefs. Methods Ecol. Evol. 6, 1088-1096. doi:10.1111/2041210X.12380

Mumby, P.J., Steneck, R.S., 2008. Coral reef management and conservation in light of rapidly evolving ecological paradigms. Trends Ecol. Evol. 23, 555-563. doi:10.1016/j.tree.2008.06.011

Narayan, S., Beck, M.W., Reguero, B.G., Losada, I.J., van Wesenbeeck, B., Pontee, N., Sanchirico, J.N., Ingram, J.C., Lange, G.-M., Burks-Copes, K.A., 2016. The Effectiveness, Costs and Coastal Protection Benefits of Natural and Nature-Based Defences. PLoS One 11, e0154735.

doi:10.1371/journal.pone.0154735

Olds, A.D., Pitt, K.A., Maxwell, P.S., Babcock, R.C., Rissik, D., Connolly, R.M., 2014. Marine reserves help coastal ecosystems cope with extreme weather. Glob. Chang. Biol. 20, 3050-3058.

doi:10.1111/gcb.12606 
Page, C., Baker, D., Harvell, C., Golbuu, Y., Raymundo, L., Neale, S., Rosell, K., Rypien, K., Andras, J., Willis, B., 2009. Influence of marine reserves on coral disease prevalence. Dis. Aquat. Organ. 87, 135-150. doi:10.3354/dao02112

Pendleton, L.H., Comte, A., Langdon, C., Ekstrom, J.A., Cooley, R., Suatoni, L., Beck, M.W., Brander, L.M., Burke, L., Cinner, E., Doherty, C., Edwards, P.E.T., Gledhill, D., Jiang, L., Hooidonk, R.J. Van, Teh, L., Waldbusser, G.G., Ritter, J., 2016a. Coral Reefs and People in a High-CO 2 World : Where Can Science Make a Difference to People ? PLoS One 11, 1-21. doi:10.1371/journal.pone.0164699

Pendleton, L.H., Hoegh-Guldberg, O., Langdon, C., Comte, A., 2016b. Multiple Stressors and Ecological Complexity Require a New Approach to Coral Reef Research. Front. Mar. Sci. 3, 1-5. doi:10.3389/fmars.2016.00036

Przeslawski, R., Ahyong, S., Byrne, M., Worheide, G., Hutchings, P., 2008. Beyond corals and fish: the effects of climate change on noncoral benthic invertebrates of tropical reefs. Glob. Chang. Biol. 14, 2773-2795. doi:10.1111/j.1365-2486.2008.01693.x

Rau, G.H., McLeod, E.L., Hoegh-Guldberg, O., 2012. The need for new ocean conservation strategies in a high-carbon dioxide world. Nat. Clim. Chang. 2, 720-724. doi:10.1038/nclimate1555

Rinkevich, B., 2015. Novel tradable instruments in the conservation of coral reefs, based on the coral gardening concept for reef restoration. J. Environ. Manage. 162, 199-205. doi:10.1016/j.jenvman.2015.07.028

Rinkevich, B., 2014. Rebuilding coral reefs: does active reef restoration lead to sustainable reefs? Curr. Opin. Environ. Sustain. 7, 28-36. doi:10.1016/j.cosust.2013.11.018

Rogers, A., Harborne, A.R., Brown, C.J., Bozec, Y., Castro, C., Chollett, I., Hock, K., Knowland, C. a., Marshell, A., Ortiz, J.C., Razak, T., Roff, G., Samper-Villarreal, J., Saunders, M.I., Wolff, N.H., Mumby, P.J., 2015. Anticipative management for coral reef ecosystem services in the 21st century. Glob. Chang. Biol. 21, 504-514. doi:10.1111/gcb.12725

Scheffer, M., 2015. Creating a safe operating space for iconic ecosystems. Science (80-. ). 347, 13171319. doi:10.1126/science.aaa3769

Schuldt, J.P., McComas, K.A., Byrne, S.E., 2016. Communicating about ocean health: theoretical and practical considerations: Table 1. Philos. Trans. R. Soc. B Biol. Sci. 371, 20150214.

doi:10.1098/rstb.2015.0214

Selig, E.R., Casey, K.S., Bruno, J.F., 2012. Temperature-driven coral decline: the role of marine protected areas. Glob. Chang. Biol. 18, 1561-1570. doi:10.1111/j.1365-2486.2012.02658.x

Selkoe, K.A., Blenckner, T., Caldwell, M.R., Crowder, L.B., Erickson, A.L., Essington, T.L., Estes, J.A., Fujita, R., Halpern, B.S., Hunsicker, M.E., Mach, M.E., Martone, R.G., Mease, L.A., Salomon, A.K., Samhouri, J.F., Scarborough, C., Stier, A.C., White, C., Zedler, J., 2015. Principles for managing marine ecosystems prone to tipping points. Ecosyst. Heal. Sustain. 1, 17. doi:10.1890/EHS14-0024.1

Serafy, J.E., Shideler, G.S., Araújo, R.J., Nagelkerken, I., 2015. Mangroves Enhance Reef Fish Abundance at the Caribbean Regional Scale 1-15. doi:10.1371/journal.pone.0142022

Shelton, A.J., Richmond, R.H., 2016. Watershed restoration as a tool for improving coral reef resilience 
against climate change and other human impacts. Estuar. Coast. Shelf Sci. 183, 430-437. doi:10.1016/j.ecss.2016.06.027

Sheppard, C., Dixon, D.J., Gourlay, M., Sheppard, A., Payet, R., 2005. Coral mortality increases wave energy reaching shores protected by reef flats: Examples from the Seychelles. Estuar. Coast. Shelf Sci. 64, 223-234. doi:10.1016/j.ecss.2005.02.016

Sippo, J.Z., Maher, D.T., Tait, D.R., Holloway, C., Santos, I.R., 2016. Are mangroves drivers or buffers of coastal acidification? Insights from alkalinity and dissolved inorganic carbon export estimates across a latitudinal transect. Global Biogeochem. Cycles 30, 753-766. doi:10.1002/2015GB005324

Strong, a. L., Kroeker, K.J., Teneva, L.T., Mease, L. a., Kelly, R.P., 2014. Ocean Acidification 2.0: Managing our Changing Coastal Ocean Chemistry. Bioscience 64, 581-592. doi:10.1093/biosci/biu072

Teh, L.S.L., Teh, L.C.L., Sumaila, U.R., 2013. A global estimate of the number of coral reef fishers. PLoS One 8. doi:10.1371/journal.pone.0065397

Toth, L.T., van Woesik, R., Murdoch, T.J.T., Smith, S.R., Ogden, J.C., Precht, W.F., Aronson, R.B., 2014. Do no-take reserves benefit Florida's corals? 14 years of change and stasis in the Florida Keys National Marine Sanctuary. Coral Reefs 33, 565-577. doi:10.1007/s00338-014-1158-x

van Oppen, M.J.H., Oliver, J.K., Putnam, H.M., Gates, R.D., 2015. Building coral reef resilience through assisted evolution. Proc. Natl. Acad. Sci. 112, 2307-2313. doi:10.1073/pnas.1422301112

Villanoy, C., David, L., Cabrera, O., Atrigenio, M., Siringan, F., Aliño, P., Villaluz, M., 2012. Coral reef ecosystems protect shore from high-energy waves under climate change scenarios. Clim. Change 112, 493-505. doi:10.1007/s10584-012-0399-3

Weatherdon, L. V., Magnan, A.K., Rogers, A.D., Sumaila, U.R., Cheung, W.W.L., 2016. Observed and projected impacts of climate change on marine fisheries, aquaculture, coastal tourism, and human health: an update, Frontiers of Marine Science. Frontiers. doi:10.3389/fmars.2016.00048

West, J.M., Salm, R. V., 2003. Resistance and Resilience to Coral Bleaching: Implications for Coral Reef Conservation and Management. Conserv. Biol. 17, 956-967. doi:10.1046/j.1523-1739.2003.02055.x

Williamson, P., Bodle, R., 2016. Update on Climate Geoengineering in Relation to the Convention on Biological diversity: Potential Impacts and Regulatory Framework, Technical. ed. Secretariat of the Convention on Biological Diversity, Montreal. doi:10.13140/RG.2.2.10957.23522

Wolff, N.H., Donner, S.D., Cao, L., Iglesias-Prieto, R., Sale, P.F., Mumby, P.J., 2015. Global inequities between polluters and the polluted: climate change impacts on coral reefs. Glob. Chang. Biol. 21, 3982-3994. doi:10.1111/gcb.13015

Zeller, D., Palomares, M.L.D., Tavakolie, A., Ang, M., Belhabib, D., Cheung, W.W.L., Lam, V.W.Y., Sy, E., Tsui, G., Zylich, K., Pauly, D., 2016. Still catching attention: Sea Around Us reconstructed global catch data, their spatial expression and public accessibility. Mar. Policy 70, 145-152. doi:10.1016/j.marpol.2016.04.046

Zeppel, H., 2012. Collaborative governance for low-carbon tourism: climate change initiatives by \{Australian\} tourism agencies. Curr. Issues Tour. 15, 603-626. doi:10.1080/13683500.2011.615913 
Figure S1: Authors affiliations per country for the four categories of management strategies (A-D)

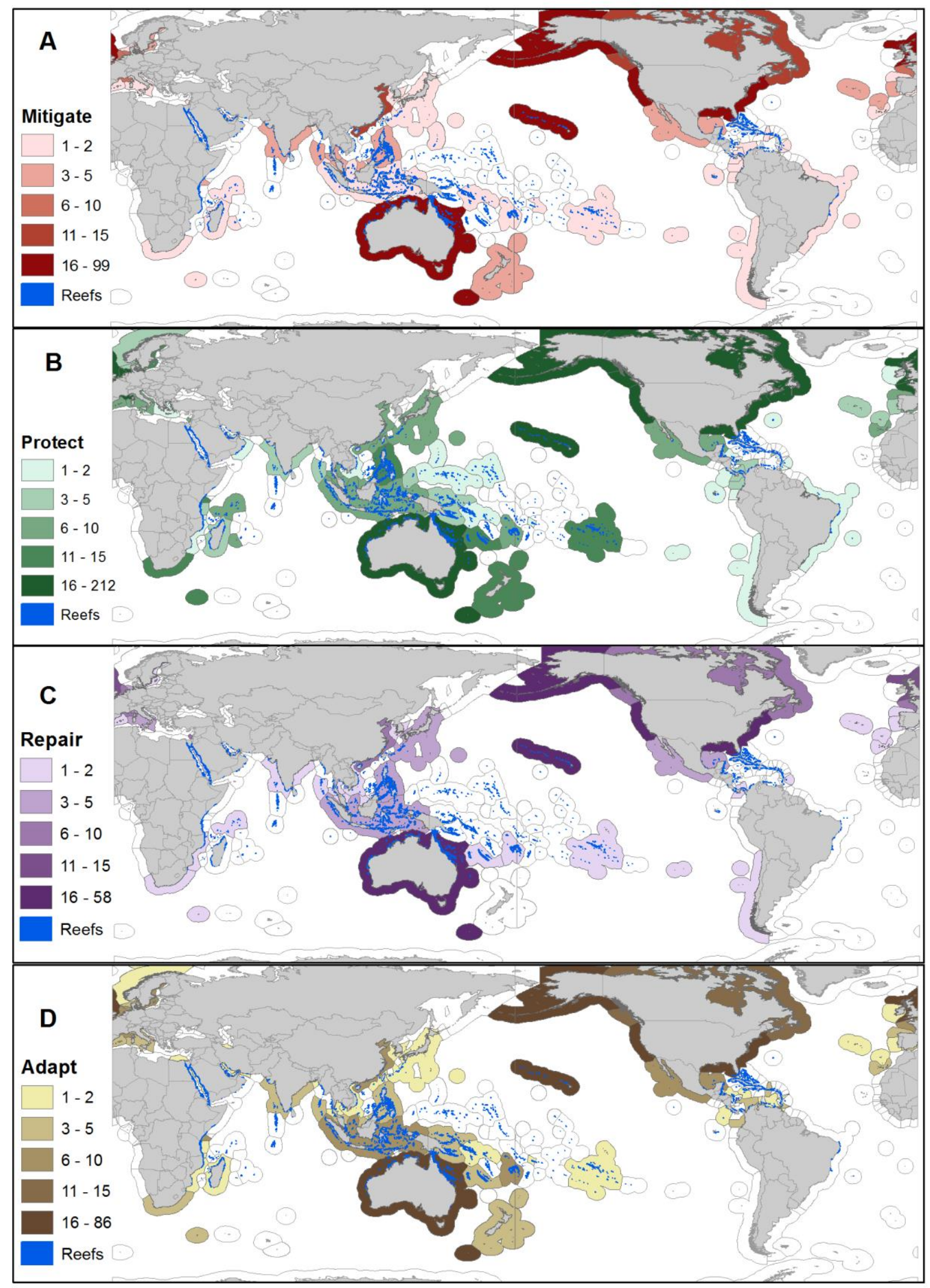


Figure S2: Case studies per country for the four categories of management strategies (E-H)

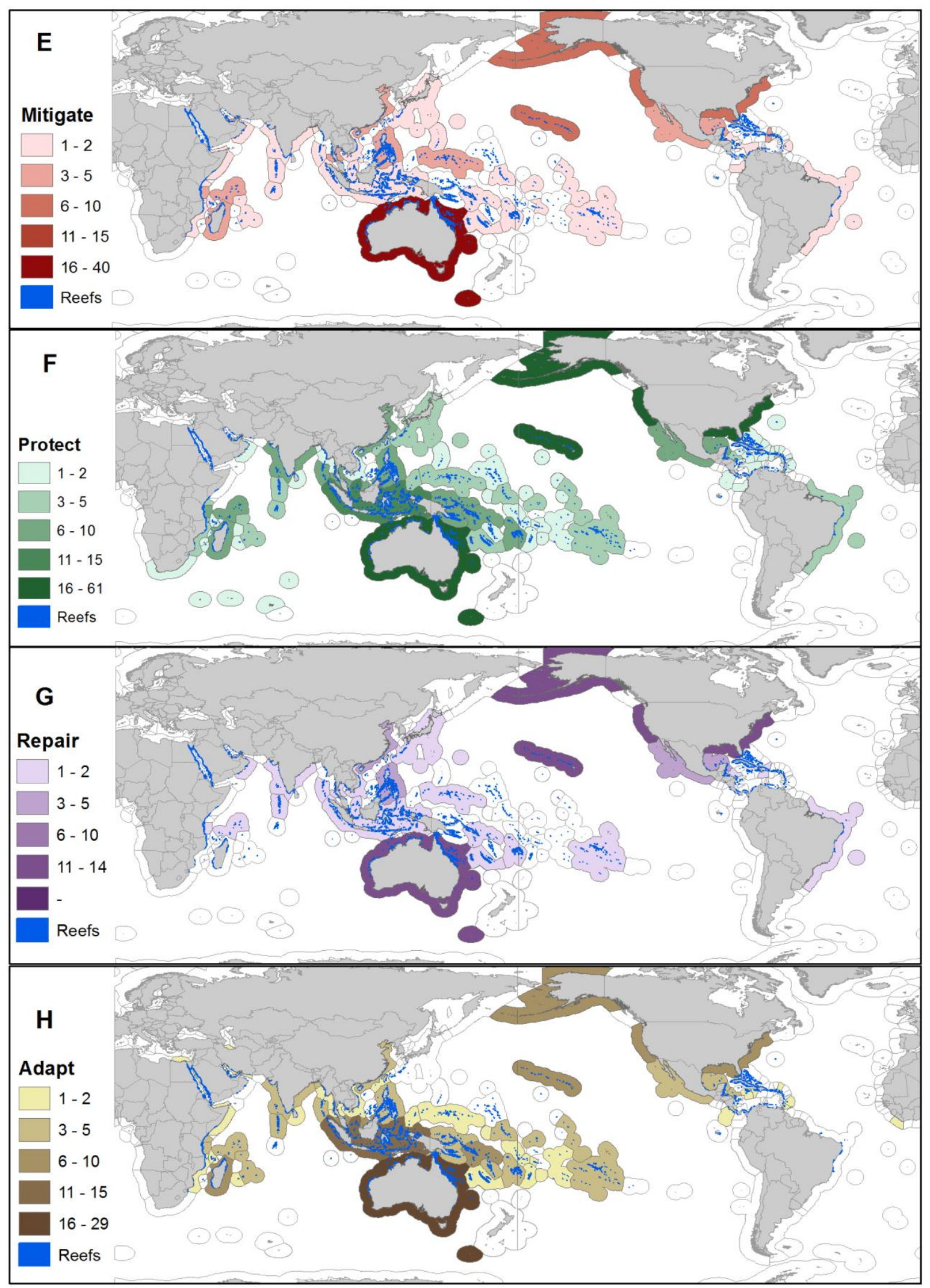

